\title{
Article \\ Nationwide Assessment of Water Quality in Rivers across Lebanon by Quantifying Fecal Indicators Densities and Profiling Antibiotic Resistance of Escherichia coli
}

\author{
Lea A. Dagher ${ }^{1}$, Jouman Hassan ${ }^{2}$, Samer Kharroubi ${ }^{1}\left[\right.$ (D) Hadi Jaafar ${ }^{3}\left[\right.$ and Issmat I. Kassem ${ }^{1,2, *}$ (i) \\ 1 Department of Nutrition and Food Sciences, Faculty of Agricultural and Food Sciences, American University \\ of Beirut (AUB), Beirut 1107 2020, Lebanon; lad17@mail.aub.edu (L.A.D.); sk157@aub.edu.lb (S.K.) \\ 2 Center for Food Safety, Department of Food Science and Technology, University of Georgia, \\ 1109 Experiment Street, Griffin, GA 30223, USA; Jouman.Hassan@uga.edu \\ 3 Department of Agriculture, Faculty of Agricultural and Food Sciences, American University of Beirut (AUB), \\ Beirut 1107 2020, Lebanon; hj01@aub.edu.lb \\ * Correspondence: issmat.kassem@uga.edu
}

Citation: Dagher, L.A.; Hassan, J.; Kharroubi, S.; Jaafar, H.; Kassem, I.I. Nationwide Assessment of Water Quality in Rivers across Lebanon by Quantifying Fecal Indicators Densities and Profiling Antibiotic Resistance of Escherichia coli. Antibiotics 2021, 10, 883. https:/ / doi.org/10.3390/antibiotics10070883

Academic Editors:

Massimiliano Marvasi and Anna Psaroulaki

Received: 14 June 2021

Accepted: 16 July 2021

Published: 20 July 2021

Publisher's Note: MDPI stays neutral with regard to jurisdictional claims in published maps and institutional affiliations.

Copyright: (c) 2021 by the authors. Licensee MDPI, Basel, Switzerland. This article is an open access article distributed under the terms and conditions of the Creative Commons Attribution (CC BY) license (https:/ / creativecommons.org/licenses/by/ $4.0 /)$.

\begin{abstract}
The use of contaminated water has been associated with severe disease outbreaks. Due to widespread pollution with untreated sewage, concerns have been raised over water quality in Lebanon, a country with well-documented challenges in infrastructure. Here, we evaluated the water quality of major rivers in Lebanon by quantifying the densities of fecal indicator bacteria (fecal coliforms and Escherichia coli). Additionally, we assessed the dissemination of antibiotic-resistant E. coli in river water. Composite water samples $(n=132)$ were collected from fourteen rivers, and $378 \mathrm{E}$. coli were isolated and analyzed. Fecal coliforms and E. coli were detected in $96.29 \%$ and $95.5 \%$ of the samples, respectively. Additionally, $73.48-61.3 \%$ and $31.81 \%$ of the samples exceeded the microbiological acceptability standards for irrigation and the fecal coliform limit for recreational activities, respectively. The E. coli exhibited resistance to ampicillin (40\% of isolates), amoxicillin + clavulanic acid $(42 \%)$, cefepime $(4 \%)$, cefotaxime $(14 \%)$, cefalexin $(46 \%)$, cefixime $(17 \%)$, doripenem $(0.3 \%)$, imipenem $(0.5 \%)$, gentamicin $(6 \%)$, kanamycin $(9 \%)$, streptomycin $(35 \%)$, tetracycline $(35 \%)$, ciprofloxacin $(10 \%)$, norfloxacin $(7 \%)$, trimethoprim-sulfamethoxazole (32\%), and chloramphenicol (13\%). Notably, $45.8 \%$ of the isolates were classified as multidrug resistant (MDR). Our results highlight the need to urgently address fecal pollution and the dissemination of antibiotic resistance in Lebanese rivers.
\end{abstract}

Keywords: water quality; rivers; fecal pollution; fecal indicators; fecal coliforms; E. coli; antibiotic resistance; agriculture; recreation; Lebanon

\section{Introduction}

Natural water resources such as rivers are vital assets with a substantial impact on human health, food production, and the economy. The increase in the human population has intensified demand on water resources for both critical needs, such as agriculture and sanitation, and recreation. Furthermore, threats like pollution and climate change have contributed to water scarcity and the deterioration of water quality, increasing further the pressure on vital water resources and their sustainability worldwide [1-3].

The association of water pollution with adverse impacts on human health and the contamination of food is well documented [4]. While around $62 \%$ of irrigated lands worldwide primarily rely on surface waters [5], contaminated waters have resulted in outbreaks of disease with considerable incidences of morbidity and mortality, especially in children and other vulnerable populations [2,6-8]. This is not surprising because polluted water is known to harbor a variety of microbial pathogens, including bacteria, viruses and parasites, and chemical contaminants. For example, in the United States of America (US) recently, exposure to contaminated recreational water has resulted in outbreaks caused by Shigella 
(California), norovirus (Maine), or Shiga toxin-producing Escherichia coli (Minnesota) $[9,10]$. Furthermore, irrigation water has been potentially linked to the contamination of leafy greens, which was associated with several foodborne disease outbreaks in the US caused by E. coli O157:H7 and E. coli O145 [11]. Therefore, pollution is a serious unfolding problem that threatens water quality and requires immediate attention.

An emerging and significant risk associated with water pollution is the emergence and/or dissemination of antibiotic-resistant (ABR) bacterial pathogens that can cause lifethreatening and difficult-to-treat infections $[12,13]$. In fact, the World Health Organization (WHO) recognizes antimicrobial resistance as one of the most urgent public health threats that is associated with widespread suffering and economic losses. Similarly, the United Nations Environment Programme (UNEP) has designated antimicrobial resistance as one of the top six emerging environmental issues [14]. Surface waters are readily contaminated with antibiotics and resistant bacteria from a variety of sources and activities $[13,15,16]$ such as the direct disposal of untreated wastewater into water resources, including rivers, or via runoff from agricultural fields amended with manure [17-19]. Wastewater is considered a reservoir of ABR bacteria and can also contain excreted and/or discarded antibiotics used for medical and/or agricultural purposes [20]. Notably, 30-90\% of some antibiotics can be excreted unmetabolized from humans and animals after consumption [21,22]. These antibiotics will then exert a pressure on bacterial communities driving the selection, evolution, emergence, and/or persistence of antibiotic-resistant bacteria, which are then disseminated by water to humans and animals [21,22].

Water pollution and associated problems, including the spread of ABR, are exacerbated in developing countries due to several factors that include debilitated infrastructure, the lack of proper sewage and waste disposal systems, and weak water quality surveillance programs [23]. Notably, poor water quality and sanitation have been linked to $80 \%$ of all diseases, while $\sim 1.8$ million people die yearly due to waterborne diseases in developing countries [24]. The latter has an indelible impact on fragile socioeconomic development, increasing the cycle of poverty and suffering in these countries [24,25]. The World Bank estimates that water pollution can claim approximately a third of economic growth in some countries [26]. Consequently, there is a paramount need to monitor water quality and devise interventions and recommendations to limit the multi-pronged impacts associated with the pollution of water resources, especially in developing countries with substantial deficiencies in resources and infrastructure.

Lebanon is a developing Mediterranean country with numerous challenges that include a weak infrastructure, severe economic crisis, political unrest, and widespread pollution among others. In comparison to other countries in the Middle East and North Africa (MENA) region, Lebanon is considered to be relatively water rich $[19,27,28]$. However, water in Lebanon have been suffering from chronic mismanagement, partially due to the absence of a national policy for integrated water resources management, which prevents the country from exploiting this valuable resource [28]. Furthermore, water in Lebanon has been under an increasing pollution threat, mainly due to (1) population growth, including an influx of $\sim 1.5$ million refugees ( $\sim 1$ refugee per 4 nationals) since 2011 , (2) wastewater and solid waste mismanagement, and (3) absence of monitoring and surveillance programs [29-33]. Notably, in 2016, it was reported that only $58.54 \%$ of buildings in Lebanon were connected to a sewer network, while the rest $(41.46 \%)$ use cesspools, septic tanks, or directly dispose untreated sewage into aquatic environments such as rivers and streams. It was also estimated that only $11.65 \%$ and $6.87 \%$ of the population in the North of Lebanon and Beirut (capital of Lebanon) and Mount Lebanon were connected to serviceable sewage networks, respectively $[33,34]$. Additionally, sewage water is not properly treated, because there is insufficient number of wastewater treatment plants (WWTPs) in Lebanon, while available WWTPs provide preliminary treatment, operate with limited capacity and budget, or lack a sewage network, rendering the plants largely nonoperational [33-35]. As a result, 92\% of the collected wastewater are disposed of without any prior treatment into aquatic environments [33]. The aforementioned pollution strongly 
suggests that surface water might be widely contaminated and constitutes a reservoir that disseminates contaminants such as antibiotic resistant pathogens to other vital resources, including the food chain. Recently, multiple reports have highlighted a rise in antibiotic resistance in Lebanon [30,36-42] due to the abuse and misuse of antibiotics in humans and agriculture [43]. This problem appears to be widespread, with multidrug and extensively drug-resistant bacteria detected in clinical settings [43-45], farmed animals [36,38,46-48], and the environment $[30,37,39,40]$. However, studies on the occurrence of ABR in polluted surface waters, especially rivers, are sparse and limited in Lebanon $[19,27,49]$.

Lebanon depends on water for agriculture (60\% of water withdrawal) and municipal (29\%) and industrial use (11\%) [50]. Furthermore, it was estimated that $45 \%$ of the irrigated lands in Lebanon rely on surface water as a primary source [3]. Consequently, water pollution in Lebanon poses a significant risk to public health and the economy. Here, we assessed the water quality and occurrence of antibiotic-resistant bacteria in all major rivers $(n=14)$ across Lebanon. For this purpose, we quantified indicators of fecal pollution, fecal coliforms, and E. coli [51-53], from samples collected from upstream, midstream, and downstream of each river. This is important because high densities of fecal indicators have been associated with the occurrence of pathogenic microorganisms such as Salmonella and E. coli O157:H7 that have serious impact on human health [51]. Furthermore, antibiotic resistance was evaluated using E. coli isolated from the water because this bacterium has also been used as an indicator for monitoring the emergence and proliferation of resistance in bacterial communities [54-56]. To our knowledge, this is the first nationwide study that assessed water quality and antibiotic resistance across all rivers in Lebanon.

\section{Materials and Methods}

\subsection{Collection of Water Samples from Rivers across Lebanon}

Freshwater samples were collected from 14 major perennial rivers across Lebanon (May-July 2019). Two of these rivers, the Assi and Hasbani, are transboundary. Each river was divided into three sampling sites, upstream (U), midstream (M), and downstream (D), that were $\sim 7-42 \mathrm{~km}$ apart depending on the length of the river and accessibility of the location. For the Litani river, which is the longest $(>165 \mathrm{~km})$ and largest river in Lebanon, three midstream (M) locations were included in the sampling. Composite samples were aseptically collected in triplicates from each sampling site by submerging a sterile 1 Liter Nalgene ${ }^{\circledR}$ water bottle, 20-30 cm underwater without disrupting the sediment as recommended by the US Environmental Protection Agency (EPA) [40,57]. A total of one-hundred and thirty-two $(n=132)$ freshwater samples from 44 locations (Table 1$)$ were transported to the laboratory in coolers $\left(2-5^{\circ} \mathrm{C}\right)$ and processed within $12-16 \mathrm{~h}$ of collection.

Table 1. Sampling locations across the major rivers in Lebanon, upstream (U), midstream (M), and downstream (D). Sample identifiers (ID) are included for each sampling location. For example, Wak, Hed, and Ari represent Wadi Khaled, Hekr el Dahri, and Arida, which are upstream, midstream, and downstream of the Kabir river, respectively. Major rivers are listed in order from the North to the South of Lebanon. * Inaccessible: the location was across the Lebanese borders and could not be sampled.

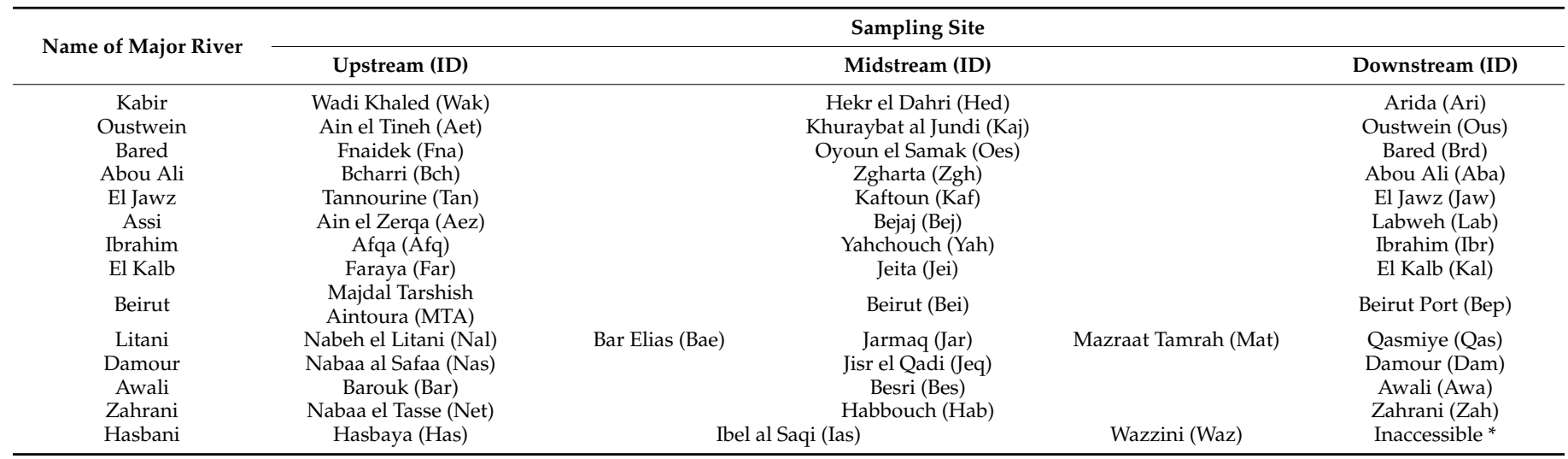




\subsection{Quantification of Fecal Coliforms and E. coli Densities}

To determine the number of colony forming units (CFU) of fecal coliforms and E. coli, the water samples were filtered $(100 \mathrm{~mL}$ and $500 \mathrm{~mL})$ through a $0.22-\mu \mathrm{m}$ Millipore ${ }^{\circledR}$ membranes (Sigma-Aldrich, St. Louis, MO, USA). The membranes were transferred onto RAPID'E. coli 2 agar plates (BioRad, Hercules, CA, USA) that were incubated at $44{ }^{\circ} \mathrm{C}$ for 18-24 $\mathrm{h}$ under aerobic conditions [37,58]. Typical CFUs of fecal coliforms (blue) and E. coli (violet to pink) colonies were counted and reported as CFU/100 mL water. The microbiological quality of the samples was determined by comparing the fecal indicator loads to the United States Environmental Protection Agency (US-EPA) standards for recreational water (permissible limit of fecal coliforms; $800 \mathrm{CFU} / 100 \mathrm{~mL}$ ) [51] and the SEQ-EAU-2003 standard for irrigation (permissible limit of thermo-tolerant coliforms; $100 \mathrm{CFU} / 100 \mathrm{~mL}$ ) [59].

To facilitate comparison between fecal coliforms and E. coli counts, bacterial densities were averaged from the triplicates of each sampling location, and the data were reported as average counts (CFU/100 mL) with standard error. The student $\mathrm{t}$-test was then used to compare the average counts of E. coli and fecal coliforms at each location. A p-value $<0.05$ was used to identify statistically significant differences.

\subsection{Assessment of the Antibiotic Resistance Phenotypes of the E. coli Isolates}

Antibiotic resistance profiles of the E. coli isolated from water were determined using the disk diffusion assay [60]. A total of $378 \mathrm{E}$. coli isolates ( 3 colonies per sample) were purified. Random colonies $(n=60)$ were selected and their identity further confirmed using species-specific PCR analysis as described elsewhere [30,37]. All the E. coli $(n=378)$ were suspended in cation-adjusted Muller-Hinton (MH) broth (Oxiod, Hampshire, UK) and the turbidity was adjusted using a $0.5 \mathrm{McF}$ arland standard and a spectrophotometer (Thermo Fisher Scientific, Waltham, MA, USA) [39,58]. The bacterial suspensions $(100 \mu \mathrm{L})$ were spread onto MH agar plates (Oxiod, Hampshire, UK) and commercially available antibiotic discs were added to the plates, which were then incubated at $37^{\circ} \mathrm{C}$ for $18-24 \mathrm{~h}$. The tested antibiotic discs $(n=17)$ belonged to 9 different antibiotics classes, including 1, penicillins: ampicillin (AMP; $10 \mu \mathrm{g}), 2$, beta-lactamase inhibitor combinations: amoxicillin + clavulanic acid (AMC; $20 \mu \mathrm{g} / 10 \mu \mathrm{g}$ ), 3, cephalosporins: cefixime (CFM; $5 \mu \mathrm{g}$ ), cephalexin (LEX; $30 \mu \mathrm{g})$, cefotaxime (CTX; $30 \mu \mathrm{g}$ ), and cefepime (FEP; $30 \mu \mathrm{g}) ; 4$, carbapenems: doripenem (DOR; $10 \mu \mathrm{g}$ ), meropenem (MEM; $10 \mu \mathrm{g}$ ), and imipenem (IPM; $10 \mu \mathrm{g}$ ); 5, aminoglycosides: gentamicin (GEN; $10 \mu \mathrm{g}$ ), kanamycin (KAN; $30 \mu \mathrm{g}$ ), and streptomycin (STR; $10 \mu \mathrm{g}$ ); 6, tetracyclines: tetracycline (TET; $30 \mu \mathrm{g}) ; 7$, quinolones and fluoroquinolones: ciprofloxacin (CIP; $5 \mu \mathrm{g}$ ) and norfloxacin (NOR; $10 \mu \mathrm{g}$ ); 8, sulphonamides: trimethoprim/sulfamethoxazole (SXT; $25 \mu \mathrm{g}$ ), and 9, phenicols: chloramphenicol (CHL $30 \mu \mathrm{g})$. Penicillin (PEN; $6 \mu \mathrm{g}$ ) and erythromycin (ERY; $15 \mu \mathrm{g}$ ) were used as controls, because E. coli is intrinsically resistant to these antibiotics [61]. Additionally, E. coli DH5 $\alpha$ was also included as a control across the experiments. Antibiotic resistance (ABR) was determined by measuring the diameter of the zone of inhibition around each antibiotic disc and comparing it with the Clinical and Laboratory Standards Institute (CLSI) [60] and the European Committee on Antimicrobial Susceptibility Testing (EUCAST) standards [62]. Antibiotic resistance profiles were analyzed using hierarchical clustering (HLC). For this purpose, the resistance or susceptibility of each isolate were coded in Excel ${ }^{\circledR}$ (Microsoft, Redmond, WA, USA) as follows: -1 (resistant), 0 (intermediate), and 1 (susceptible); with the E. coli isolates represented in rows and the antibiotics in columns. Then the data were exported to $\mathrm{MeV}$ v4.6.2 software (http:/ / www.tm4.org/, accessed on 10 June 2021) to perform HLC analysis using the Pearson correlation as a distance metric and the complete linkage method $[58,63]$. A graphical presentation (heat map) was generated with the upper limit (1; sensitive), midpoint (0; intermediate), and lowest limit ( -1 , resistant) colored green, black, and red, respectively [63]. 


\section{Results}

\subsection{Densities of Fecal Coliforms and E. coli in River Water Samples}

Fecal coliforms were detected in $127(96.2 \%)$ of 132 water samples and $43(98 \%)$ of 44 locations (only in one location, Fnaidek, all 3 samples did not yield fecal coliforms CFUs) (Figure 1). The average number of fecal coliforms in positive locations ranged from $1 \times 10^{0} \mathrm{CFU} / 100 \mathrm{~mL}$ to $3.66 \times 10^{4} \mathrm{CFU} / 100 \mathrm{~mL}$. E. coli was detected in $126 \mathrm{sam}-$ ples $(95.5 \%)$ and in $42(95.5 \%)$ of 44 locations (Figure 1$)$. The average number of E. coli in positive locations ranged from $2.6 \times 10^{0} \mathrm{CFU} / 100 \mathrm{~mL}$ to $2.61 \times 10^{4} \mathrm{CFU} / 100 \mathrm{~mL}$ (Figure 1). Average numbers of fecal coliforms were higher than E. coli in all positive locations; however, statistically higher average numbers of fecal coliforms $(p<0.05)$ were noted for 27 locations (Figure 1). The highest average counts were recorded in samples retrieved from the midstream of Beirut river $\left(3.66 \times 10^{4} \mathrm{CFU} / 100 \mathrm{~mL}\right.$ fecal coliforms and $2.61 \times 10^{4} \mathrm{CFU} / 100 \mathrm{~mL}$ E. coli) followed by midstream and downstream of the Abou Ali river [Zgharta $\left(2.16 \times 10^{4} \mathrm{CFU} / 100 \mathrm{~mL}, 1.1 \times 10^{4} \mathrm{CFU} / 100 \mathrm{~mL}\right)$ and Abou Ali $\left.\left(9.97 \times 10^{3} \mathrm{CFU} / 100 \mathrm{~mL}, 5.43 \times 10^{3} \mathrm{CFU} / 100 \mathrm{~mL}\right)\right]$ (Figure 1). With the exception of Abou Ali, Awali, and Hasbani rivers, the fecal coliforms and E. coli counts were generally lower upstream in comparison with those from midstream and downstream locations in the majority of the rivers (Figure 1).

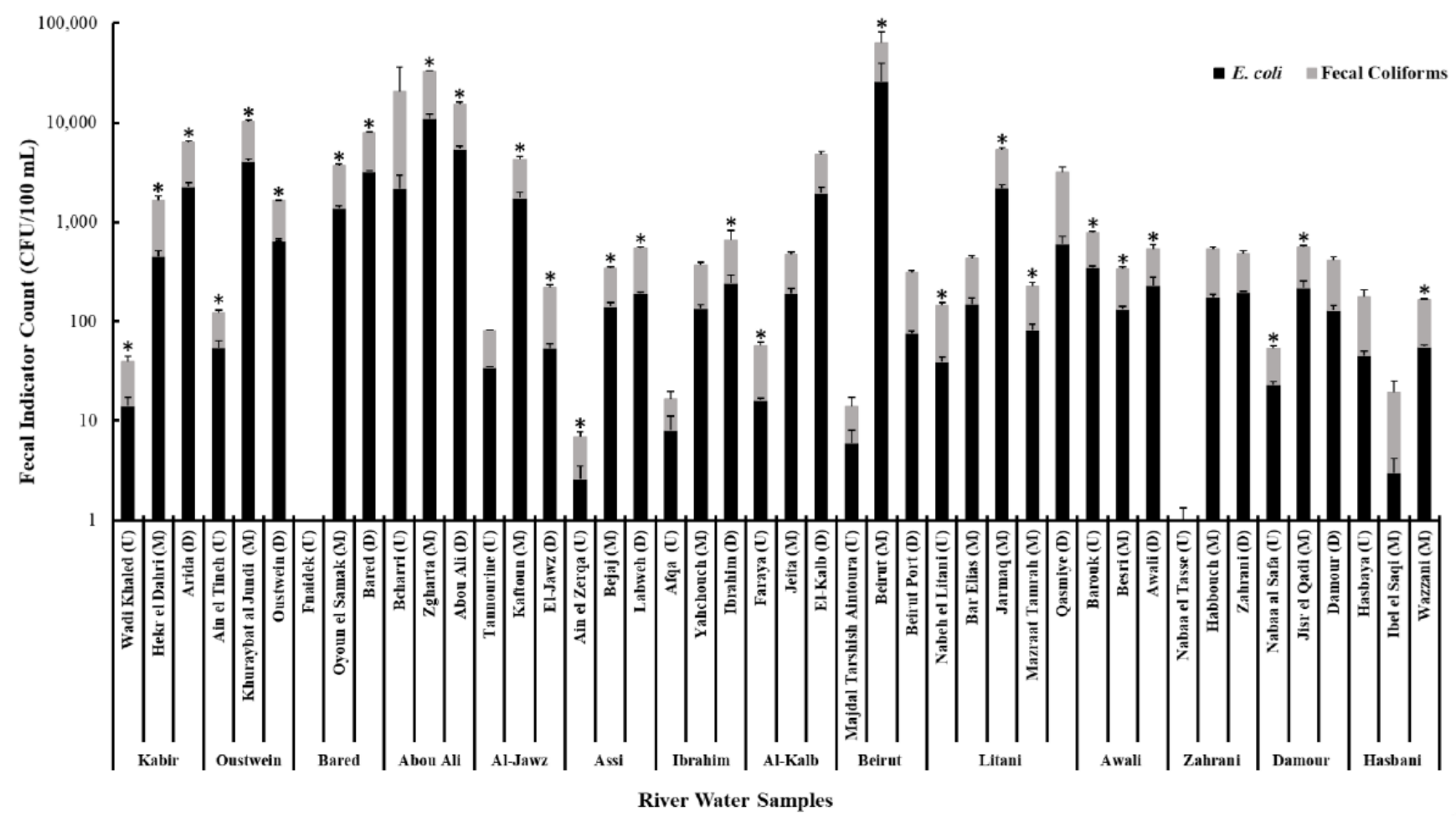

Figure 1. The average loads of fecal coliforms and E. coli counts (CFU/100 mL) in Lebanese river water. The asterisk $\left(^{*}\right)$ represents a statistically significant difference between fecal coliforms and E. coli counts $(p<0.05)$. The letters next to the sampling sites represents the location where the sample was collected, $\mathrm{U}=$ upstream, $\mathrm{M}=$ midstream, and $\mathrm{D}=$ downstream. Standard error bars are included with the averages.

\subsection{Comparison of Fecal Coliforms and E. coli Counts to Irrigation and Recreation Standards}

Fecal coliforms and E. coli counts were compared with the SEQ-EAU standard $(100 \mathrm{CFU} / 100 \mathrm{~mL})$ for irrigation water quality. Based on fecal coliforms counts, $97(73.48 \%)$ of the 132 water samples and $33(75 \%)$ of the 44 locations exceeded the SEQ-EAU-2003 standard (Figures 2 and 3), indicating that the water was unacceptable for irrigation. Similarly, when evaluating E. coli counts, it was found that $81(61.3 \%)$ of the 132 samples and $27(61.3 \%)$ of the 44 sampling locations exceeded the SEQ-EAU standard (Figures 2 and 3). 
In general, most of the samples that exceeded the permissible limit for irrigation (using fecal coliforms and/or E. coli counts) were collected from midstream and downstream locations across the major rivers. The fecal coliform counts in upstream samples from Litani and Hasbani ( 2 of 3 samples/location) rivers exceeded the standard for irrigation (Figure 2). However, when considering E. coli counts, only upstream samples from Abou Ali and Awali rivers were found to be unacceptable (Figure 2).

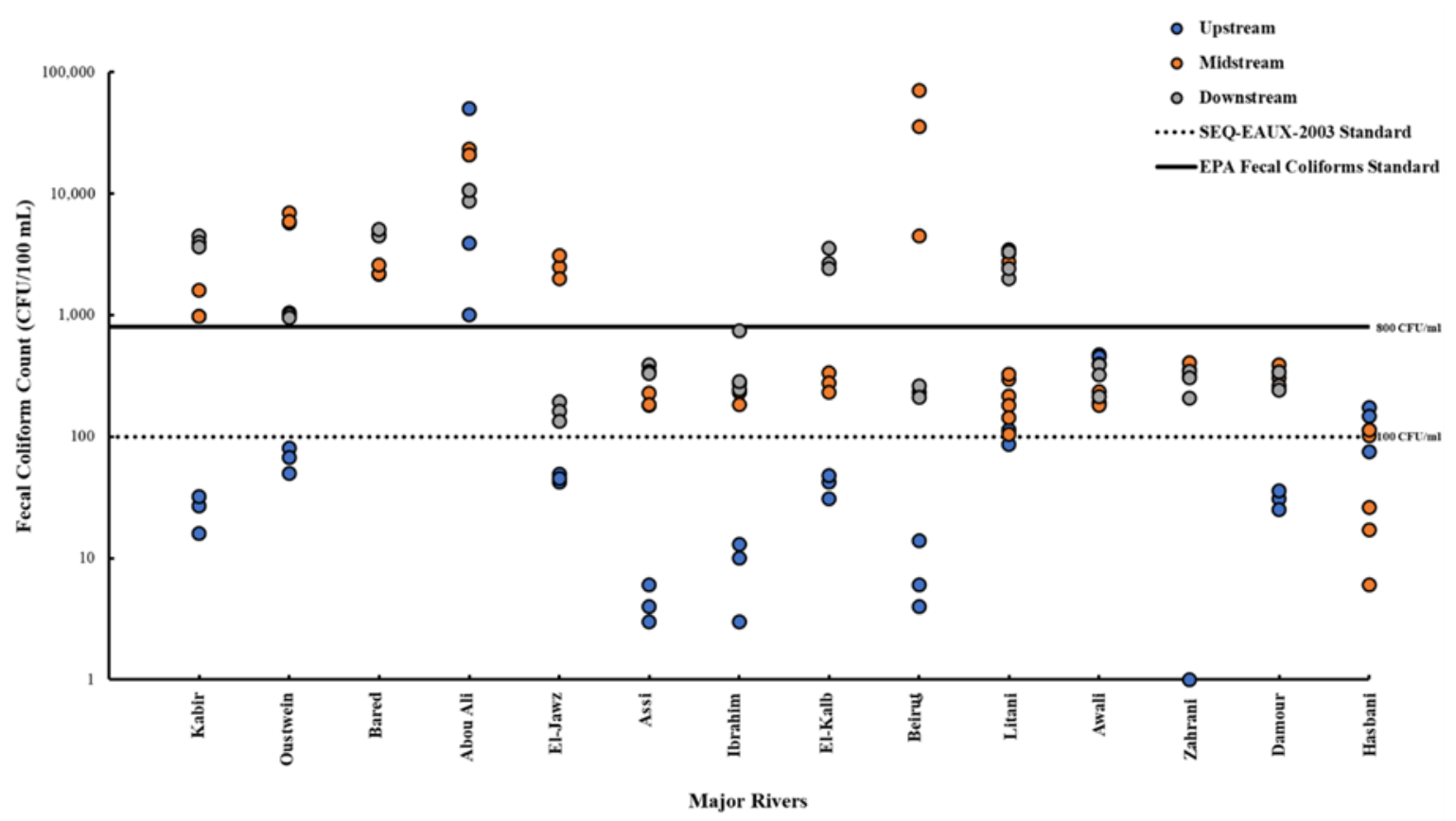

(A)

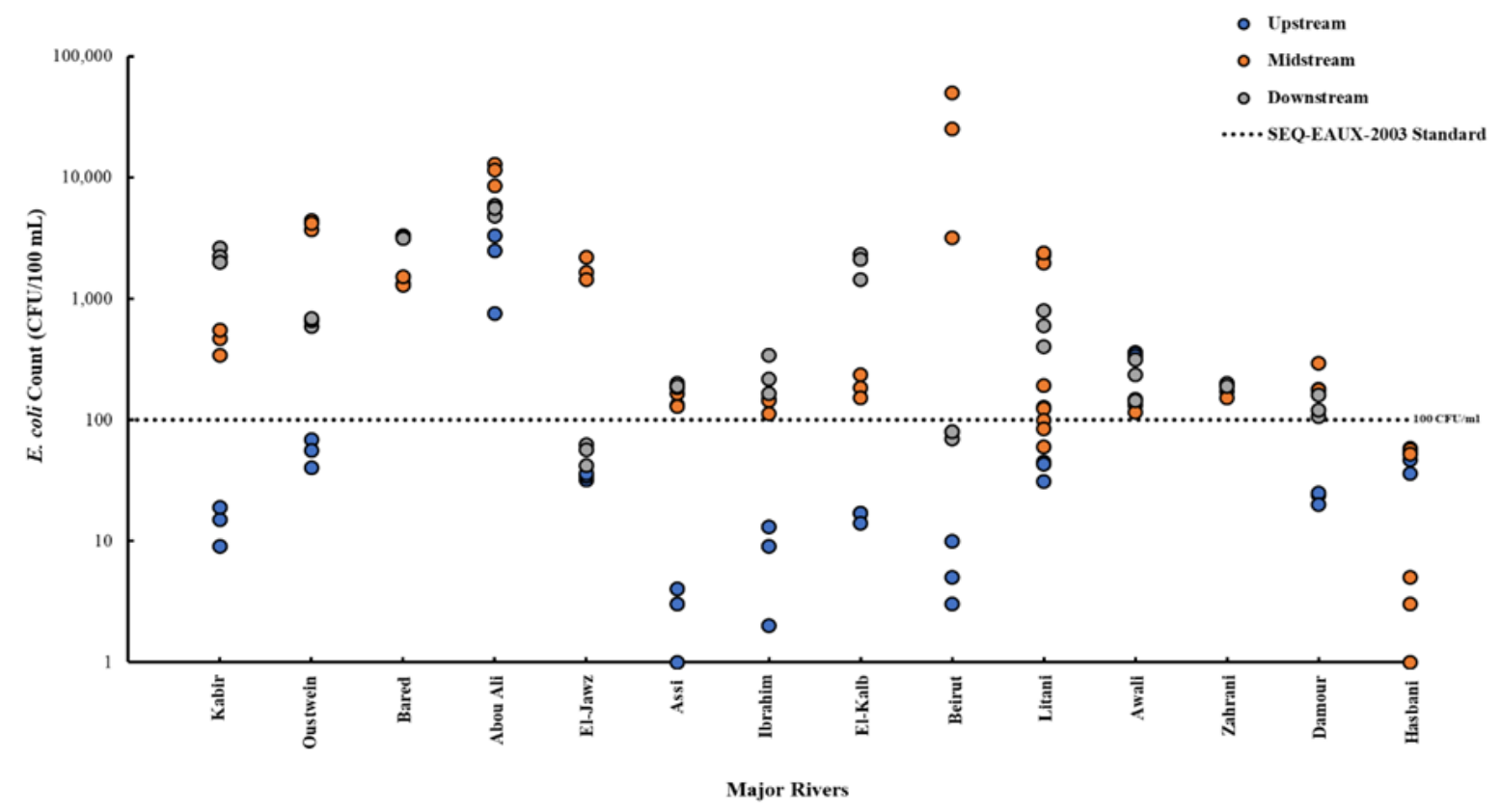

(B)

Figure 2. Distribution of counts of fecal coliforms (A) and E. coli (B) in samples collected from each location across the rivers: Upstream (blue circle), Midstream (orange), and Downstream (grey). The dotted black line indicates acceptable limit of thermo-tolerant coliforms based on the SEQ-EAUX-2003 standard for irrigation water (100 CFU/100 mL). The black line indicates the permissible limit of fecal coliforms for safe recreational water ( $800 \mathrm{CFU} / 100 \mathrm{~mL})$ as per the EPA standards. Samples that did not yield fecal coliforms or E. coli are not represented in the figures. 

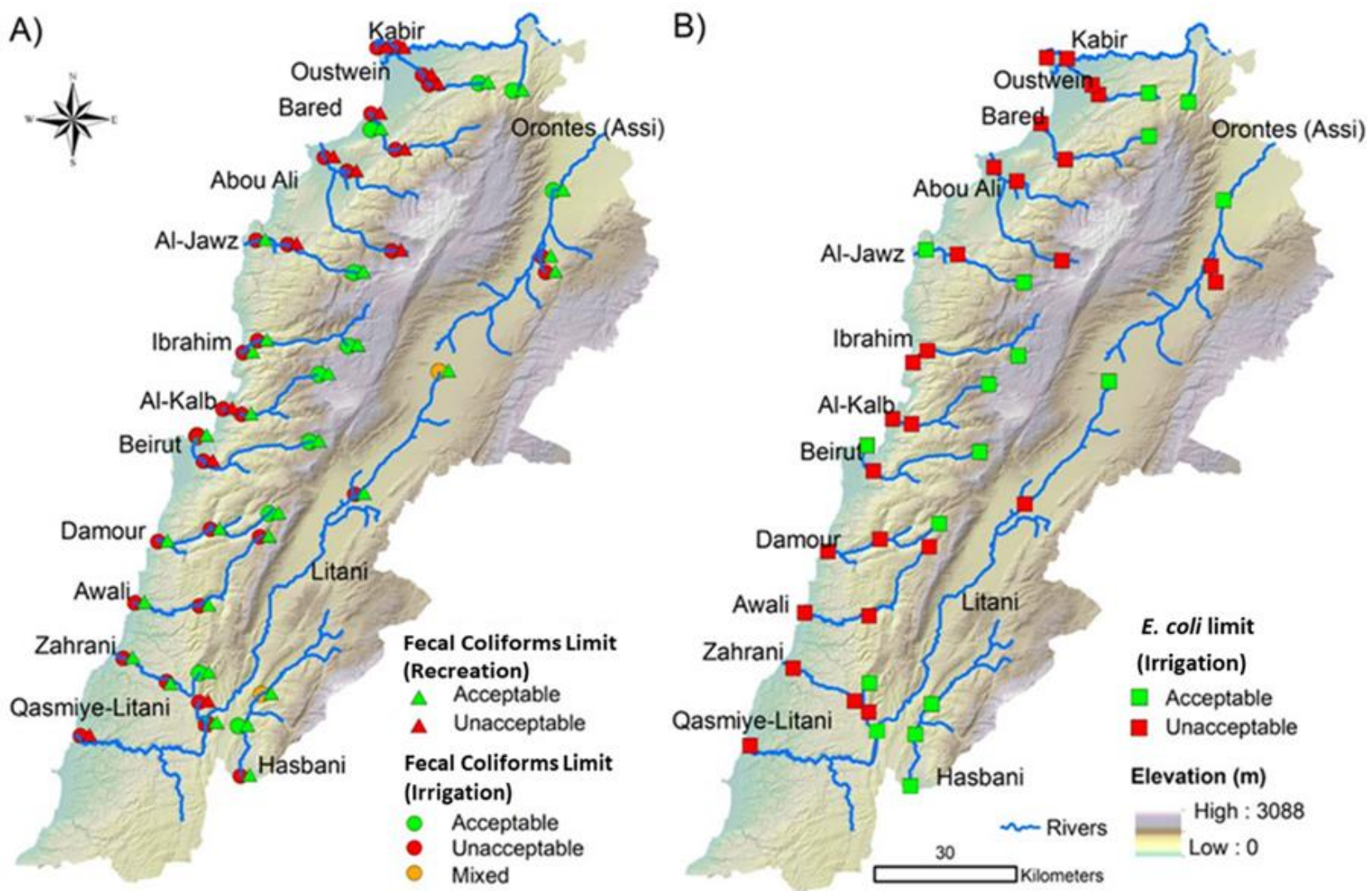

Figure 3. Map showing the distribution of the water samples that exceeded the acceptable limits for irrigation and recreational use. (A) Assessment of the acceptability of water for irrigation and recreation using fecal coliforms numbers. Red circle: all samples exceeded acceptability limits for irrigation (unacceptable); green circle: all samples were below the acceptability limit for irrigation (acceptable); orange circles: 2 samples of 3 exceeded limits for irrigation (mixed). Red triangle: all samples exceeded limits for recreation; green triangle: all samples were below the acceptability limit for recreation. (B) Assessment of acceptability of water for irrigation using E. coli numbers. Red square: all samples exceeded limits for irrigation (unacceptable); green square: all samples were below the acceptability limit for irrigation (acceptable).

The acceptability of river water for recreation was evaluated using the US-EPA standard (800 fecal coliforms CFU /100 mL). Subsequently, 42 (31.8\%) of the 132 samples and $14(31.8 \%)$ of the 44 locations exceeded the recommended standard for safe recreational use. Again, samples that exceeded the standard were collected from midstream and downstream locations; with the Abou Ali river being an exception, where all samples and locations exceeded the standard. Notably, the majority of unacceptable water samples were collected from rivers in the North (30 of $42 ; 71.4 \%$ ) in comparison with $18 \%$ of the samples collected in the South (6 of 33) and 9\% in Mount Lebanon (3 of 33) (Figures 2 and 3).

\subsection{The Antibiotic Resistance Profiles of E. coli Isolated from Water}

Antibiotic resistance profiles of $378 \mathrm{E}$. coli ( 3 colonies per sample) were determined. The isolates exhibited resistance to ampicillin (40\%), amoxicillin + clavulanic acid (42\%), cefepime $(4 \%)$, cefotaxime $(14 \%)$, cephalexin $(46 \%)$, cefixime $(17 \%)$, doripenem $(0.3 \%)$, imipenem $(0.5 \%)$, gentamicin $(6 \%)$, kanamycin $(9 \%)$, streptomycin $(35 \%)$, tetracycline $(35 \%)$, ciprofloxacin $(10 \%)$, norfloxacin $(7 \%)$, trimethoprim + sulfamethoxazole $(32 \%)$ and chloramphenicol (13\%) (Figure 4). All isolates were sensitive to meropenem. Furthermore, intermediate resistance was observed against several antibiotics, including streptomycin $(38.26 \%)$, kanamycin (26.9\%), ampicillin (8.44\%), cefepime $(8.1 \%)$, ciprofloxacin (4.75\%), norfloxacin $(3.4 \%)$, tetracycline $(1.85 \%)$, cefotaxime $(1.85 \%)$, cefixime $(1.85 \%)$, imipenem $(1.3 \%)$, doripenem $(1 \%)$, meropenem $(0.26 \%)$, gentamicin $(0.26 \%)$, and chloramphenicol $(0.26 \%)$ (Figure 4$)$. Notably, some E. coli $(n=3)$ isolated from Oyoun el Samak (midstream 
of Bared river) and Zgharta (midstream of Abou Ali river) in the North were resistant to carbapenems (doripenem and/or imipenem) (Figure 5). Furthermore, 45.8\% $(n=173)$ of the isolates were classified as multidrug resistant (MDR; resistance to at least three classes of antibiotics). Further analysis showed that $77 \%, 72 \%, 62 \%, 55.5 \%$, and $47 \%$ of the E. coli from Beirut, Bared, Awali, Abou Ali, and Litani rivers were MDR, respectively (Figure 5). Additionally, $8.7 \%$ (33 isolates), 7.1\% (27), 6.8\% (26), and $0.52 \%$ (2) of the isolates were resistant to $5,6,7$, and 8 antibiotic classes, respectively. HLC analysis of the ABR profiles of isolates from each river showed widespread resistance to AMP, AMC, LEX, CFM, STR, TET, and SXT in most of the rivers (Figure 5). Furthermore, resistance to CIP was notable in isolates from Bared, Abou Ali, and El Jawz rivers (Figure 5).

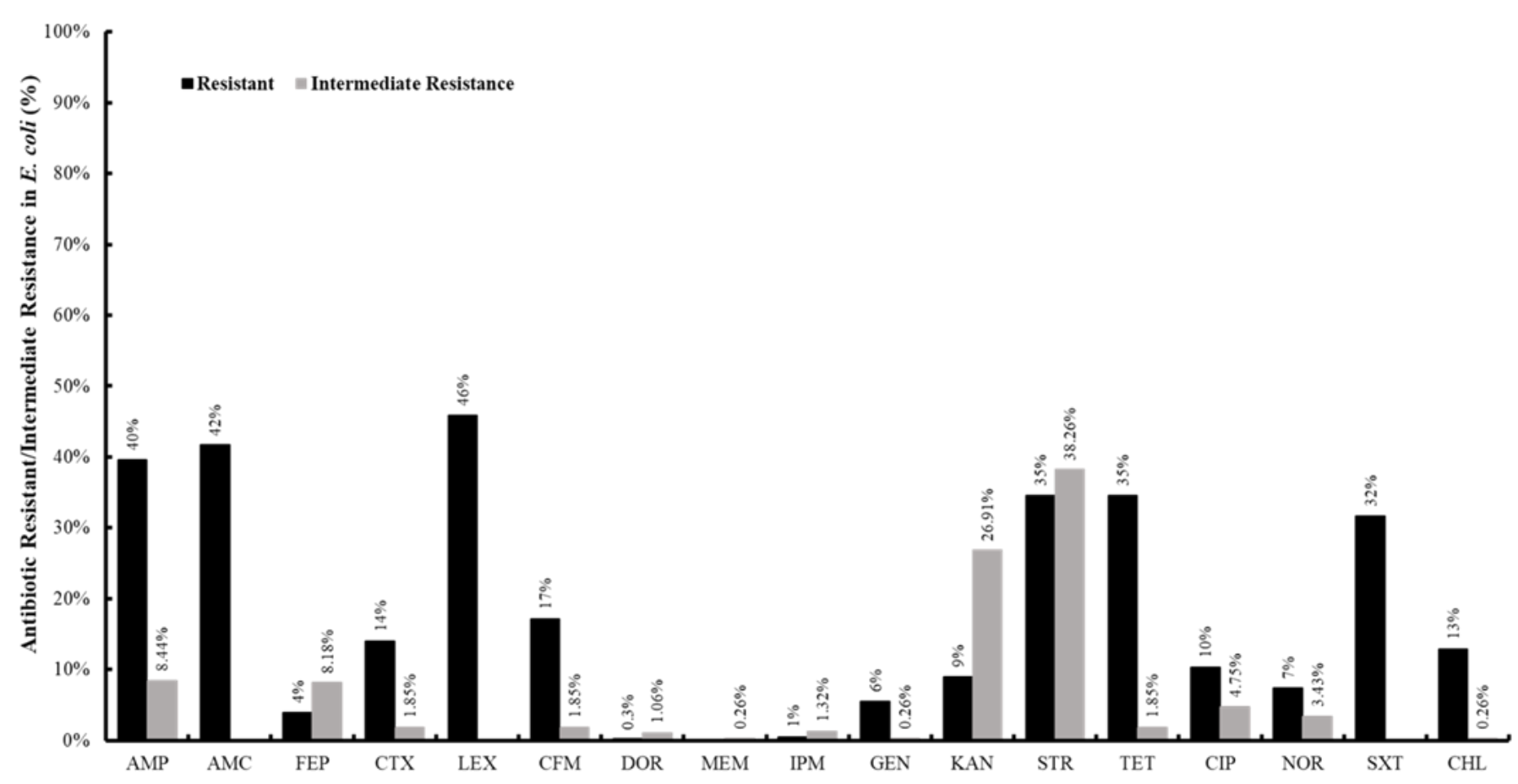

Figure 4. Antibiotic resistance of E. coli (percentage) isolated from the rivers in Lebanon. Ampicillin (AMP), amoxicillin + clavulanic acid (AMC), cefepime (FEP), cefotaxime (CTX), cephalexin (LEX), cefixime (CFM), doripenem (DOR), meropenem (MEM), imipenem (IPM), gentamicin (GEN), kanamycin (KAN), streptomycin (STR), tetracycline (TET), ciprofloxacin (CIP), norfloxacin (NOR), trimethoprim + sulfamethoxazole (SXT), and chloramphenicol (CHL). The antibiotics are arranged according to the order of antibiotics/classes listed in the CLSI guidelines. 
(A) Kabir $(n=27)$

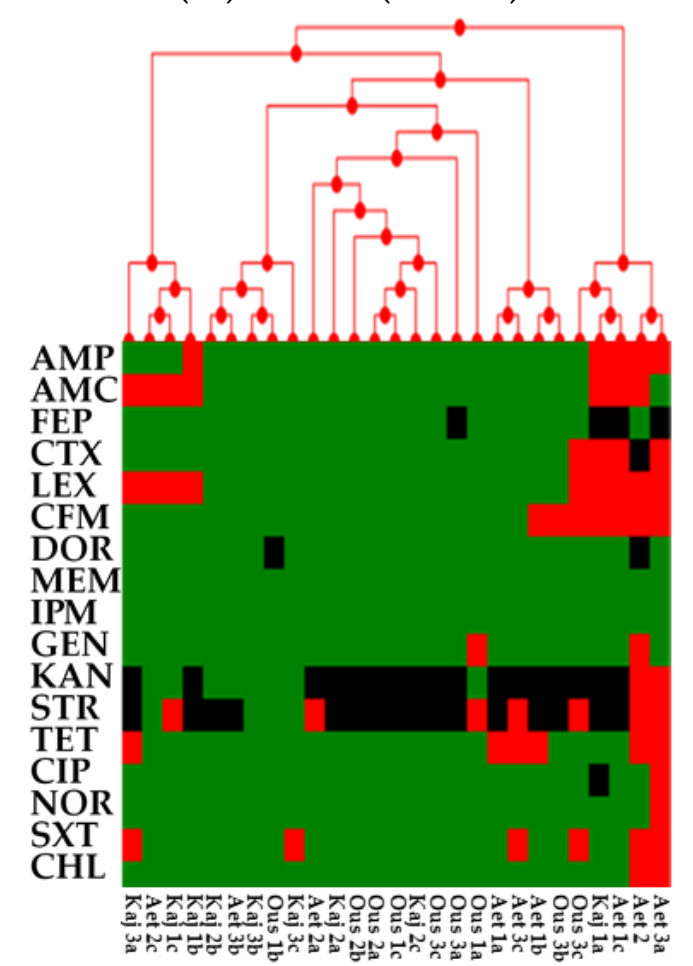

(B) Oustwein $(n=27)$

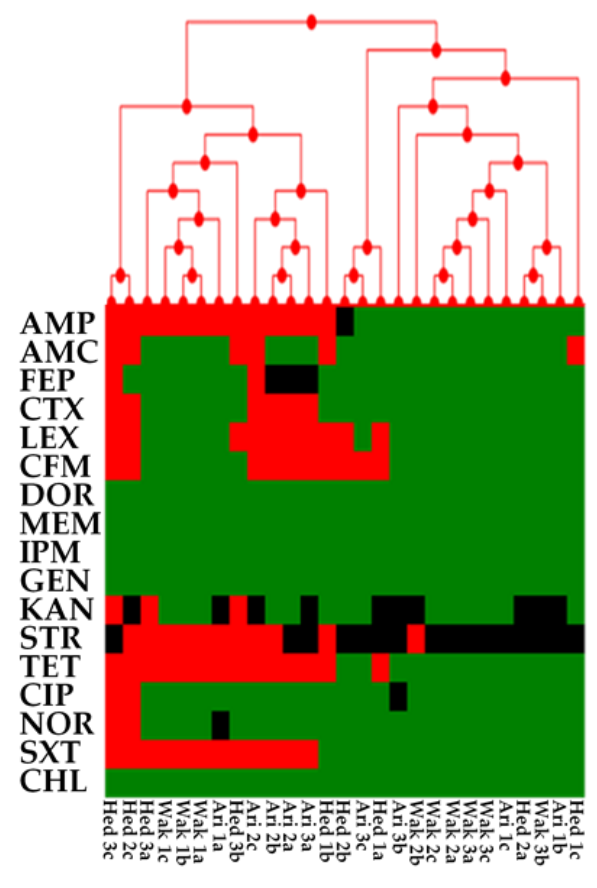

(C) Bared $(n=18)$

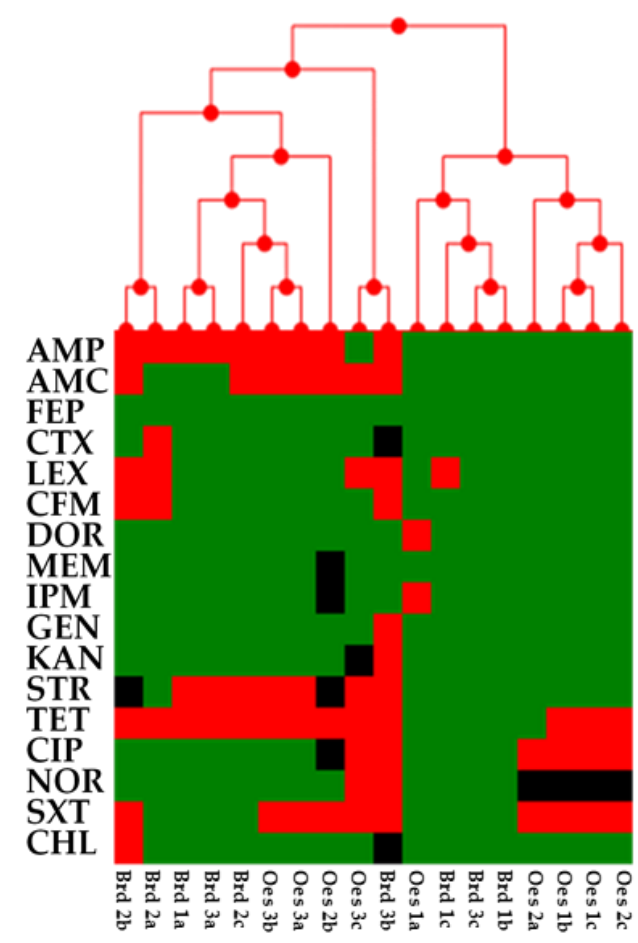

(D) Abou Ali $(n=27)$

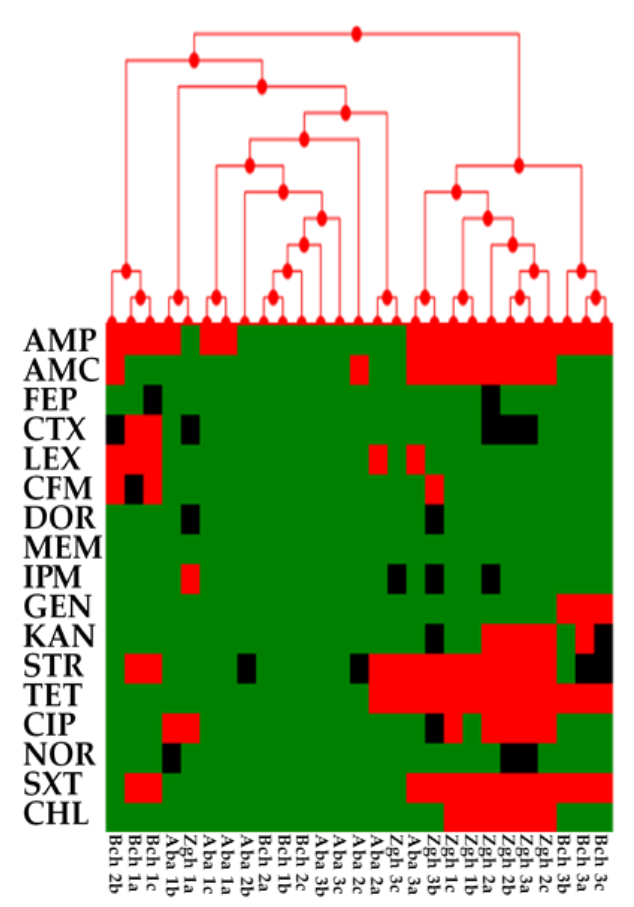

Figure 5. Cont 
(E) Al- Jawz $(n=27)$

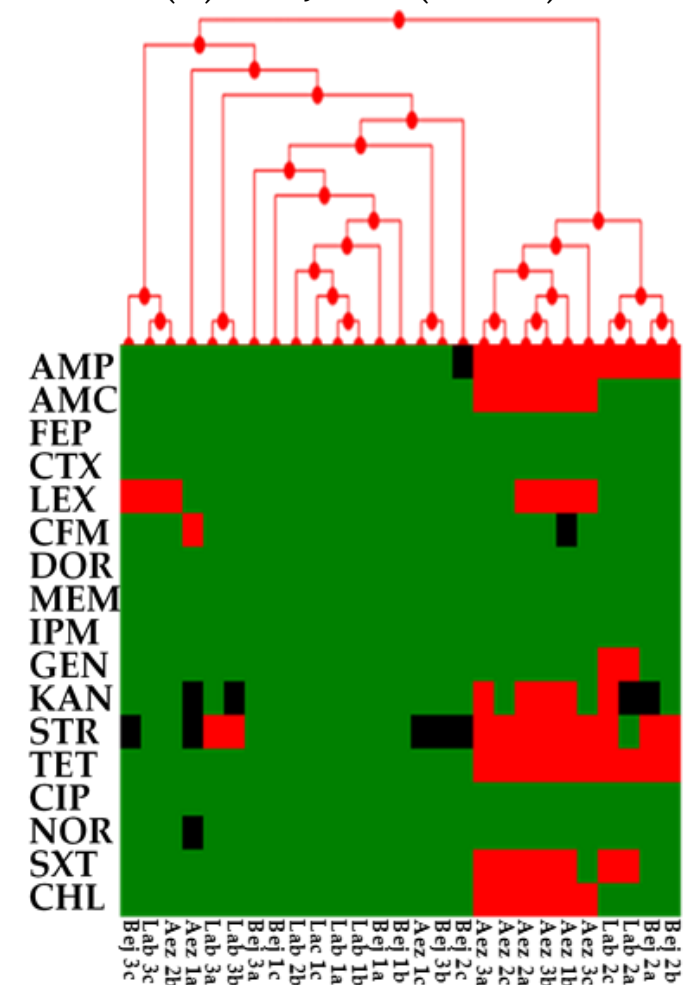

(F) Assi $(n=27)$

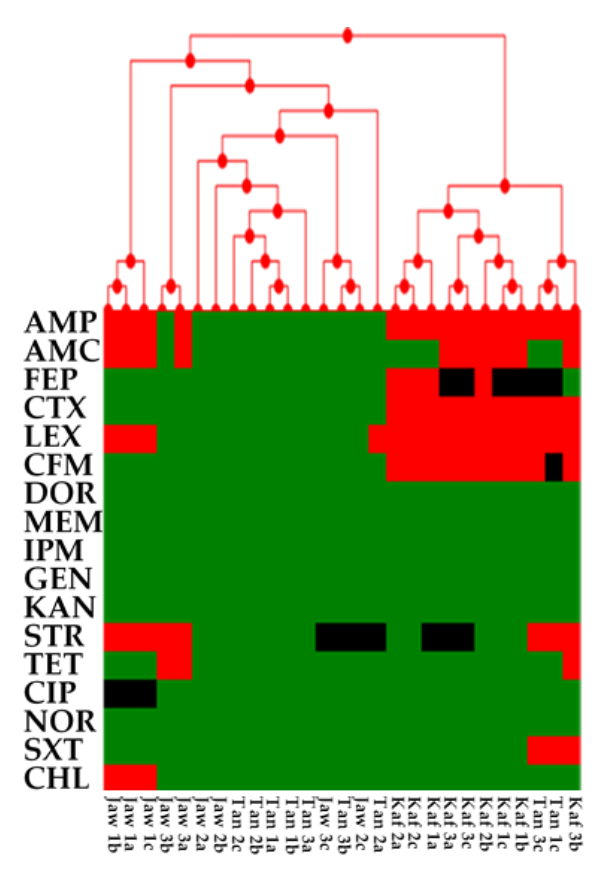

(G) Ibrahim $(n=27)$

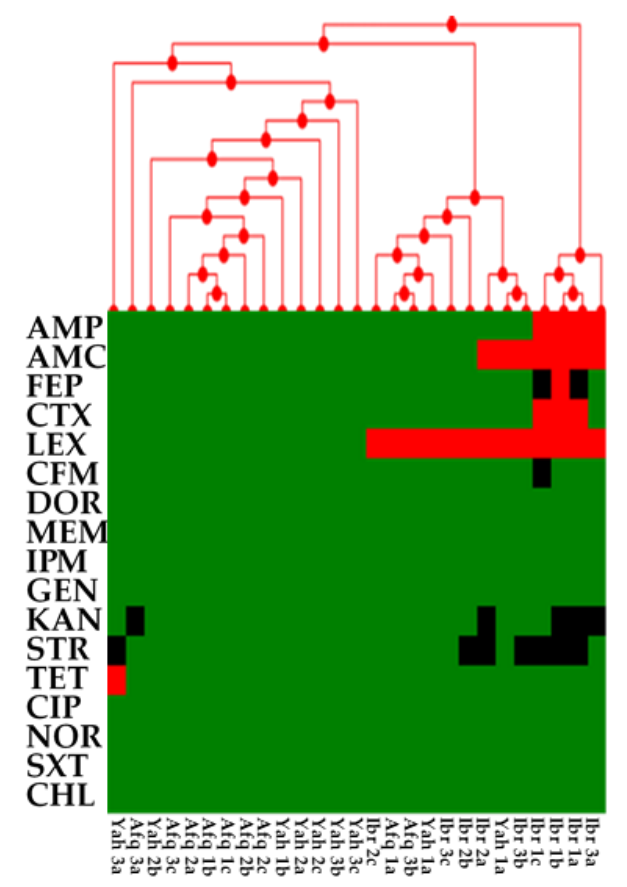

(H) Al-Kalb $(n=27)$

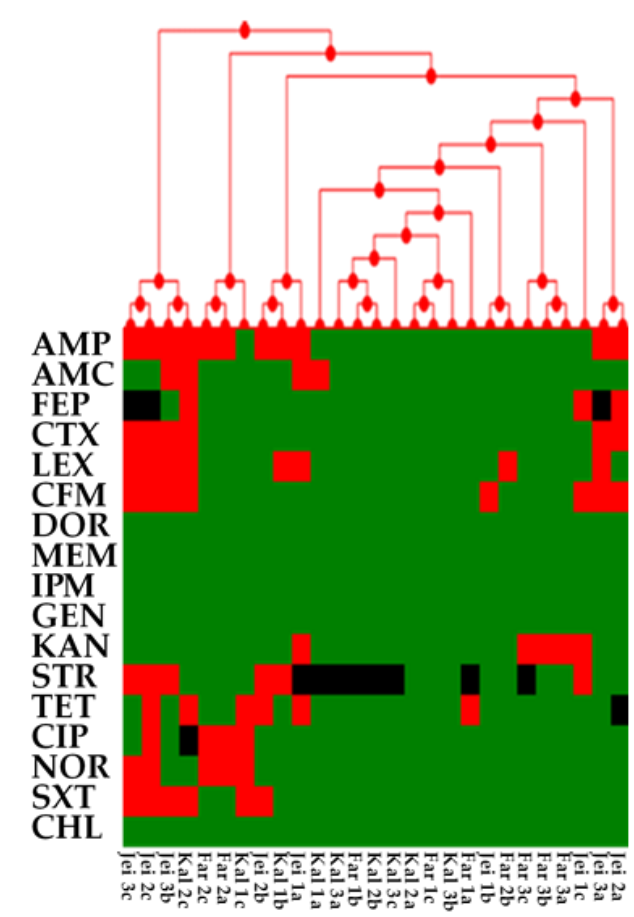

Figure 5. Cont. 
(I) Beirut $(n=27)$

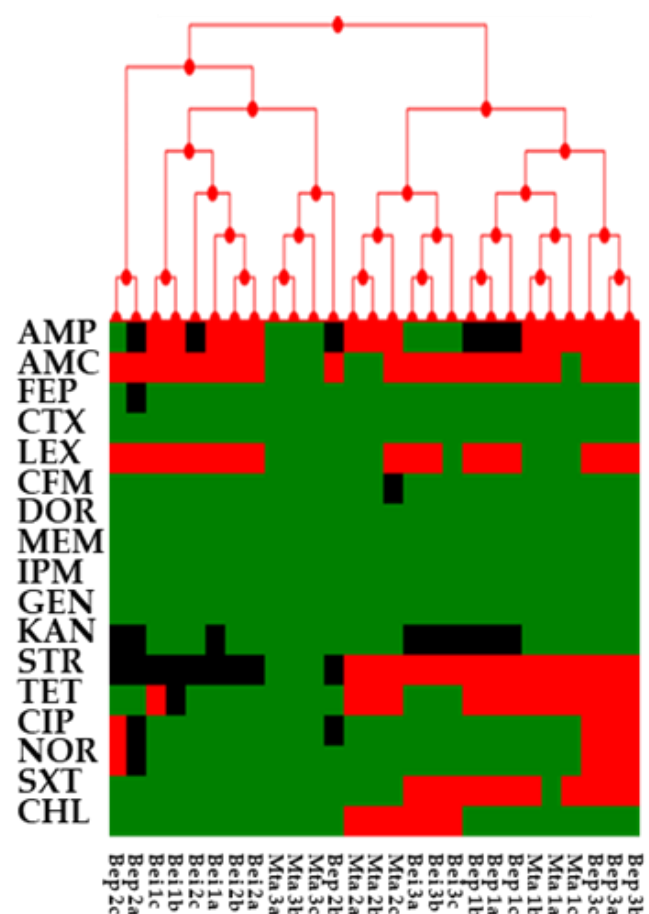

(J) Litani $(n=46)$

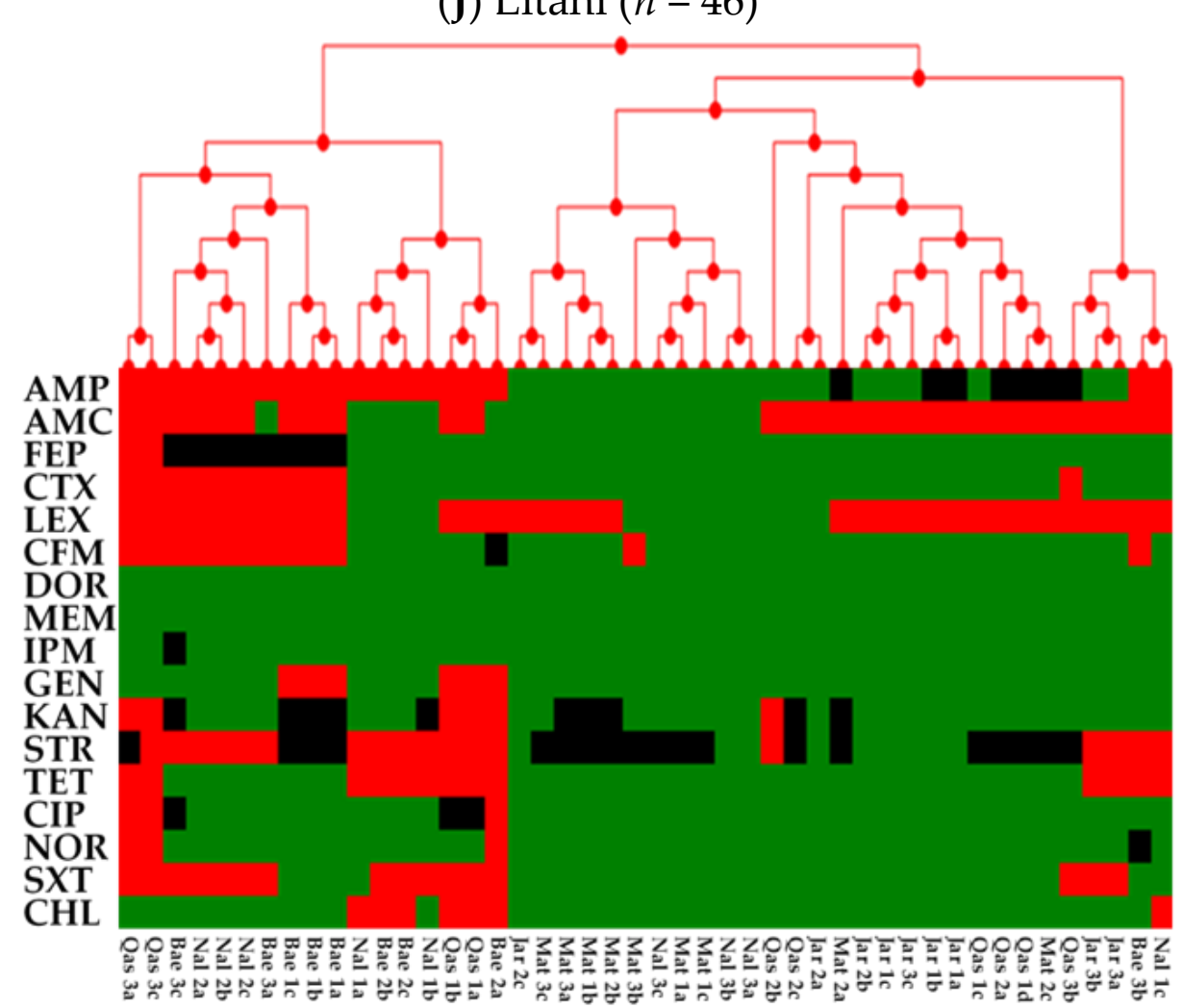

(K) Awali $(n=27)$

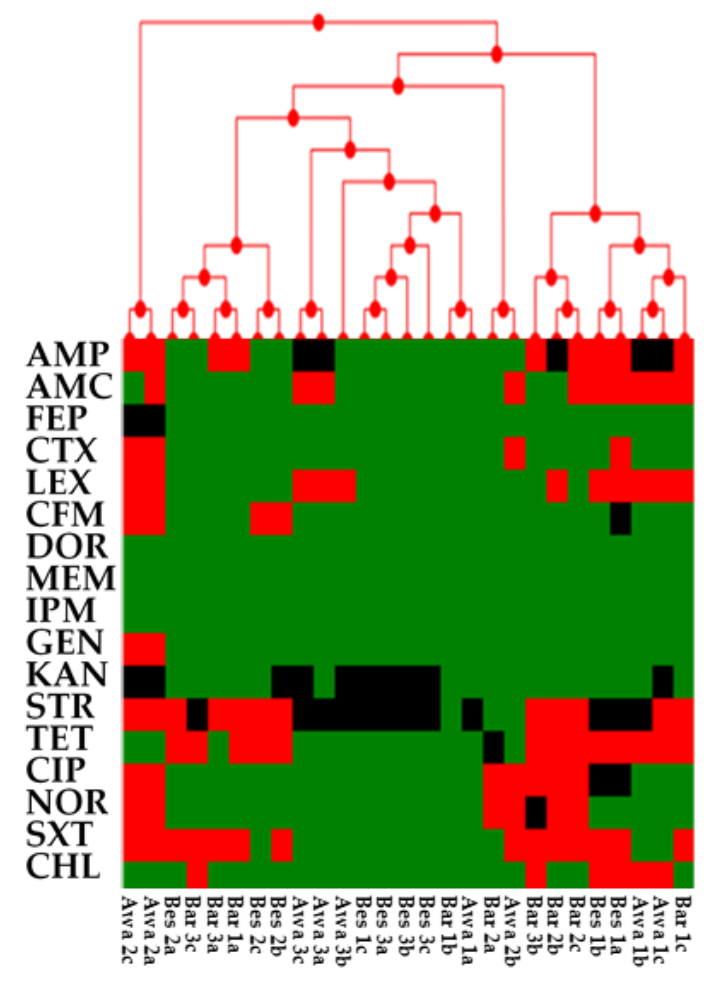

Figure 5. Cont. 

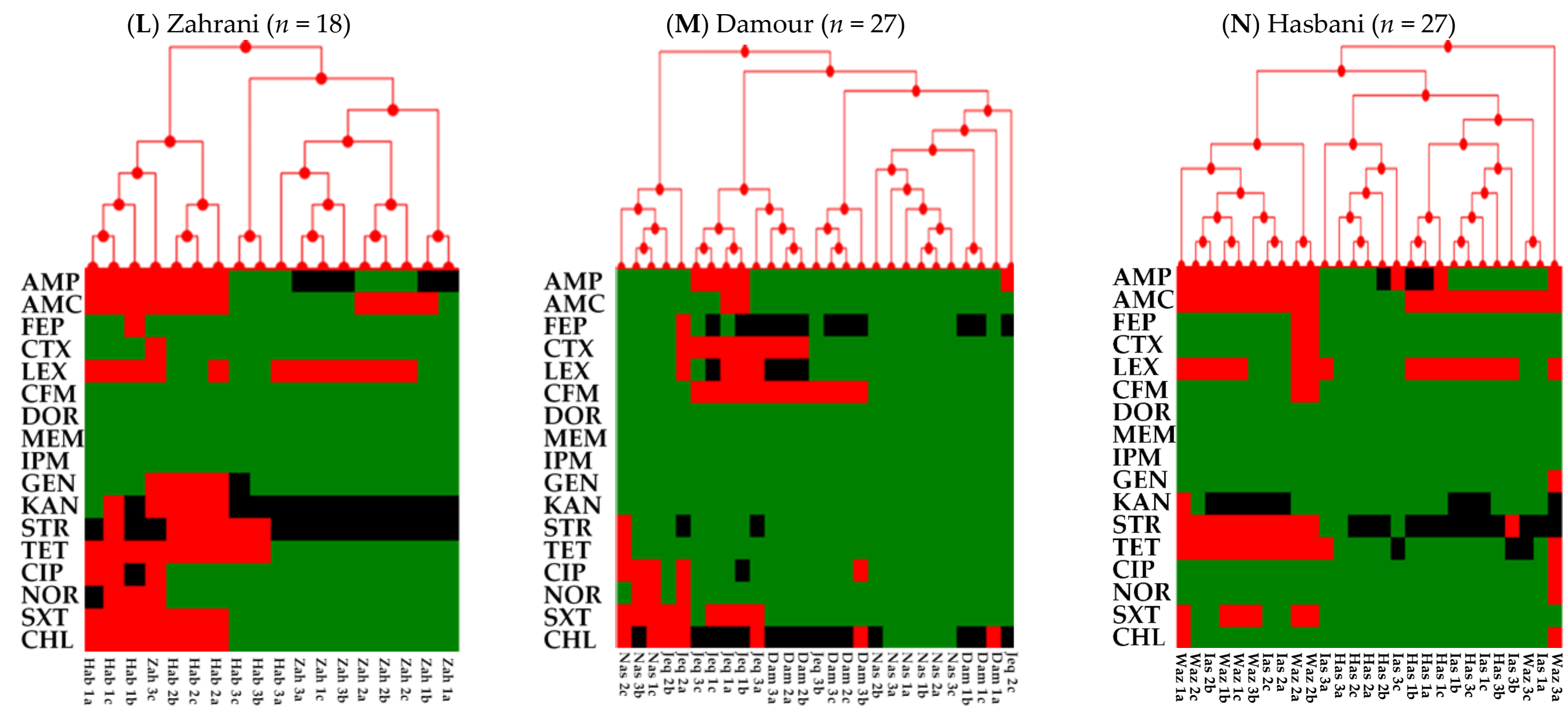

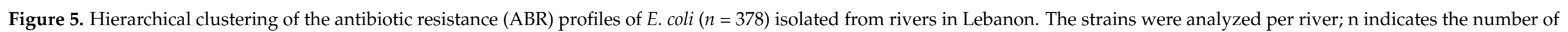

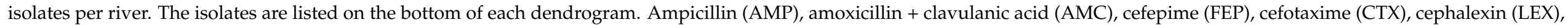

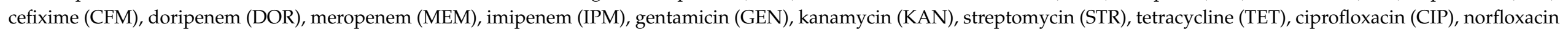

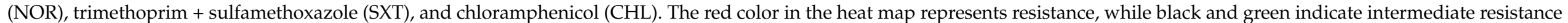
and susceptibility, respectively. 


\section{Discussion}

Clean water is an integral component in the production of safe food and in maintaining human health. The use of contaminated water results in a variety of waterborne diseases and aggravates infectious diseases and the burden of foodborne illnesses, especially in vulnerable and disenfranchised populations $[64,65]$. Therefore, it is paramount to monitor the quality of water in order to devise mechanisms and policies that prevent the contamination of vital water resources such as rivers. Despite the critical role of rivers in sustainable agriculture and socioeconomic growth in Lebanon $[5,19,27]$, river water quality has been confronted with a plethora of challenges, including severe deficiencies in infrastructure, wastewater management, and antimicrobial stewardship. Although it is widely known that aquatic environments are severely affected by untreated sewage and other agricultural and industrial contaminants $[66,67]$, studies on fecal pollution and microbial safety of surface water in Lebanon are scant. For this purpose, we conducted this study to evaluate water quality by assessing indicators of fecal pollution (fecal coliforms and E. coli) [51] and antibiotic resistance (E. coli) $[55,56]$ across all major rivers in Lebanon.

Our data showed that $96.2 \%$, and $95.5 \%$ of the river water samples in Lebanon harbored fecal coliforms and E. coli, respectively (Figures 1 and 2). The widespread detection of the fecal indicators was not surprising, given that a previous report indicated that $92 \%$ of the collected wastewater in Lebanon were discarded, without any treatment, into aquatic environments, while a considerable number of buildings lacked connection to a sewer network $[33,34,68]$. The high bacterial loads reported in some locations such as midstream of Beirut (Beirut) and Oustwein (Khuraybat el Jundi) rivers, downstream of Bared (Bared) and Kabir (Arida) rivers, and across Abou Ali river were expected because these rivers are heavily impacted by human sewage and other urban contaminants. A report in 2016 indicated that WWTPs were either absent or operated at limited capacity to treat wastewater in the North and in Beirut, which resulted in the release of untreated wastewater to aquatic environments [33,34]. Additionally, these rivers are located in areas with high population densities, including crowded refugee camps that lack infrastructure [30-33,39]. Therefore, these rivers are affected by urban activities, highlighting the negative impact of crowding and the debilitated infrastructure on water quality. Although the fecal indicators were widely detected in river water samples, it was noted that samples collected from upstream harbored relatively lower numbers of fecal coliforms and E. coli as compared with midstream and downstream samples in 11 of the 14 rivers; Abou Ali, Awali, and Hasbani rivers were the exception (Figure 1). This result suggested that the river sources were likely less affected by pollution, potentially due to limited urbanization in those locations. Therefore, as expected, the pollution (densities of fecal indicators) appears to increase as the rivers cross locations with more dense populations and increasing agricultural and industrial activities.

For assessing water quality in Lebanon, previous studies relied on international standards of fecal indicators in irrigation and recreational water. Specifically, the French SEQ-EAU-2003 [59] and the US EPA standard [51,69] have been considered for evaluating irrigation and recreational water quality, respectively. According to SEQ-EAU2003, the acceptable limit of thermo-tolerant fecal coliforms (fecal coliforms or E. coli) is $100 \mathrm{CFU} / 100 \mathrm{~mL}$, which is similar to standards set by other countries in the European Union [70], including Spain (Royal Decree 1620/2007, December 2007) [71,72]. Consequently, we adopted these standards to assess the suitability of river water for irrigation and recreation in Lebanon. When considering both fecal coliforms and E. coli numbers, it was noted that $61.3-73.48 \%$ of samples and $61.3-75 \%$ of the locations exceeded the limit set by SEQ-EAU-2003 for irrigation water (Figures 2 and 3). Therefore, E. coli densities revealed a lower number of unacceptable irrigation water samples and locations in comparison with fecal coliforms (Figures 2 and 3). However, even when considering the more conservative indicator (E. coli), we found that a majority of the unacceptable samples were located in regions where agricultural practices are relatively concentrated, which includes the North of Lebanon $(70.4 \%)$ and Beqaa $(60 \%)$. Furthermore, in the South, samples from Jarmaq 
and Qasmiye rivers, which represent the midstream and downstream of the Litani river, exceeded the SEQ-EAU-2003 standard for irrigation. This can be attributed to the fact that the Litani river flows from the Beqaa Valley and carries sewage from different cities such as Baalbeck, Bar Elias, Zahle, Joub Jannine, and Sifri as well as effluents from informal refugee settlements and many industries (such as food factories and sugar mills), poultry farms, and slaughterhouses located in the Litani basin (Figure 3) [73]. Notably, the Litani River is the chief source of irrigation for agricultural lands in the Beqaa Valley and the South, and it has been well established that the river is being subjected to different pollutants, including pesticides and human and animal waste [73,74]. For example, $\sim 69$ villages and cities release approximately $47 \mathrm{Mm}^{3}$ per year of raw sewage into the Litani River [75]. Taken together, it appears that a high number of water samples from agriculturally important rivers in Lebanon were fecally contaminated and were deemed unacceptable for irrigation. This can be further deduced by comparing the numbers with those from counties with better infrastructure and water management. For example, in Canada, of 501 irrigation water samples analyzed, only $0.8-22 \%$ exceeded the Canadian permissible limit for E. coli [76]. Furthermore, our findings suggest that human activities near the rivers significantly affect the safety of water, because most upstream sites, located in remote and less populated areas, were found to be suitable for irrigation (Figure 3). Regardless, the quality of river water is a serious concern, because fecally-contaminated irrigation water will affect the safety of produce, which will increase the risk of contracting foodborne infections that can cause serious or life-threatening diseases in humans [77,78]. Fecal pathogens like Salmonella spp., E. coli O157:H7, Cryptosporidium, Norovirus, Hepatitis A Virus among others have been associated with the contamination of produce, resulting in considerable outbreaks and/or illnesses [79]. Indeed, three studies reported that the produce such as spinach, parsley, cabbage and lettuce collected from the Beqaa Valley were contaminated with fecal bacteria $[27,80,81]$. Notably, fresh produce is usually consumed raw, which increases the risk of foodborne diseases. Therefore, it is of paramount importance to monitor the quality of water used for irrigation in order to control the proliferation of disease in Lebanon, which is particularly vulnerable to these infections due to ongoing severe medical and economic crises [82]. It should be highlighted that our study did not assess other types of contamination like pesticides and other xenobiotics, which perhaps further emphasizes the potential impact and scope of water pollution.

To assess the suitability of water for recreational use, fecal coliforms counts from the water samples were compared with the US EPA standard (Figures 2 and 3). The data showed that $31.8 \%$ of the samples were deemed unacceptable for recreational use. Notably, the majority of the samples collected from the North $(71.4 \%)$ of Lebanon were unacceptable for recreation, which is likely related to the pollution factors that were mentioned earlier. Additionally, the North has arguably more severe poverty and infrastructure challenges in comparison with the rest of the country [82]. Although $68.2 \%$ of the river samples were found to be suitable for recreational use (based on fecal coliforms counts), these results should be interpreted with caution, because (1) we only assessed fecal pollution but not other types of contamination such as chemical contaminants, (2) our sampling was cross-sectional and did not account for temporal variations in the densities of fecal indicators, (3) the sampling was done after a relatively wet season, and (4) some chemical contamination might have affected the densities of the fecal indicators. For example, pollution downstream of Beirut River (Beirut Port) from industrial, animal, and hospital wastes is well established; however, densities of fecal coliforms at this location did not exceed the EPA or SEQ-EAU-2003 standards for recreational use or irrigation. It is possible that the release of toxic chemicals (agrochemicals, detergents, chlorinated compound, etc.) might have altered the numbers of fecal coliforms in these samples [83].

It is known that even the discharge of treated sewage can release antibiotic-resistant bacteria, transmissible genetic elements that encode resistance, and antibiotics residue into environments $[84,85]$. Therefore, the emergence and dissemination of ABR has been linked to fecal pollution. Given that untreated sewage and other contaminants are released into 
Lebanese rivers and that $A B R$ is widespread in other vital matrices in Lebanon [30,36-42], it was necessary to address ABR in our samples. The latter was addressed by assessing resistance of river water E. coli, which is normally used as an indicator of ABR [86,87]. Our data showed that $173(\sim 45.8 \%)$ E. coli were multidrug resistant, exhibiting resistance to at least three antibiotic classes (Figure 5). The percentage of multidrug-resistant $E$. coli in Lebanese rivers is slightly lower than those previously reported for sewage contaminated rivers in Romania (60.34\%) [88] and in Ethiopia (78\%) [89]. However, Lebanon is a much smaller country, both in size $\left(\sim 10,450 \mathrm{Km}^{2}\right)$ and human population $(\sim 6.8$ million) and has comparatively limited agricultural and industrial output, which perhaps reveals the severity of ABR prevalence in Lebanese river water. The latter can be further evaluated, when considering countries with better wastewater management systems. For example, MDR E.coli in surface waters in the Netherlands and Poland were detected in $11 \%$ [90] and $19 \%$ [91] of the samples, respectively.

In our study, resistance to cefalexin (46\%), ampicillin (40\%), amoxicillin + clavulanic acid $(42 \%)$, streptomycin $(34 \%)$, and tetracycline $(35 \%)$, were the highest (Figure 4$)$. These antibiotics are considered clinically and agriculturally important, increasing the risk of complicated infections in swimmers, consumers of produce irrigated with contaminated waters, and livestock that might use these waters [85,92]. Resistance to carbapenems was low and only identified in three isolates from the North, specifically in Zgharta and Oyoun el Samak rivers (Figure 5). However, this should be considered a warning sign, because carbapenems are last-resort antibiotics for treating complicated life-threatening infections in humans [93]. Recently, multidrug-resistant E. coli that also harbored transmissible resistance to colistin, which is used to treat carbapenem-resistant Enterobacteriaceae (CRE) infections, was detected in irrigation water and sewage in the Beqaa region $[30,37,39]$. Taken together, it can be argued that continuous contamination might cause river water to become a reservoir for the evolution, emergence, and dissemination of MDR bacterial pathogens and ABR genetic determinants.

\section{Conclusions}

To our knowledge, this study is the first nationwide assessment of fecal pollution and the dissemination of antibiotic-resistant $E$. coli in river water in Lebanon. The data show that most of the rivers in Lebanon are heavily contaminated by fecal indicator bacteria, which jeopardizes harnessing the full potential of these critical resources in irrigation and recreation. This is further confirmed by the detection of E. coli that were resistant to clinically and agriculturally important antibiotics. Although our study was cross-sectional and did not assess other factors like water flow, chemical contamination, and seasonal variation, the results indicate clearly that fecal pollution is severely impacting rivers in Lebanon. This study highlights the urgent need to implement proper wastewater management to preserve the safety and sustainability of river water in Lebanon. Our data also suggest that fecal pollution can be remediated because the majority of upstream locations were found to be less contaminated or acceptable. However, action must be taken immediately to prevent further deterioration of the rivers. Furthermore, there is a need to strengthen antimicrobial stewardship and enhance surveillance programs to study antibiotic resistance in environmental niches in Lebanon, which remains lacking. This issue is very important locally and regionally, because river water can also carry antibioticresistant bacteria across borders and into the Mediterranean basin. The assessment of the emergence and dissemination of antibiotic resistance in water and other environments in Lebanon would benefit greatly from future studies on the underlying genetic mechanisms of resistance. Finally, we call for adopting clear and strict guidelines and standards for water safety and to continuously monitor the quality of water in Lebanese rivers, which are essential contributors to public health and economy.

Author Contributions: Conceptualization, I.I.K.; methodology, I.I.K. and H.J.; validation, I.I.K.; formal analysis, I.I.K., J.H., S.K., H.J., and L.A.D.; investigation, I.I.K., L.A.D., and J.H.; resources, I.I.K.; data curation, I.I.K., J.H., S.K., and H.J.; writing—original draft preparation, I.I.K., J.H., and 
L.A.D.; writing—review and editing, I.I.K., J.H., and H.J.; visualization, I.I.K.; supervision, I.I.K.; project administration, I.I.K.; funding acquisition; I.I.K. All authors have read and agreed to the published version of the manuscript.

Funding: This work was partially funded by a University Research Board (URB) grant from the American University of Beirut (AUB) and seed funding from the Center for Food Safety, University of Georgia (UGA).

Institutional Review Board Statement: Not applicable.

Informed Consent Statement: Not applicable.

Data Availability Statement: All the relevant data have been included in this study. We did not generate data that required public.

Acknowledgments: We thank the personnel of the Laboratory of Food Microbiology (AUB, NFSC) for their support.

Conflicts of Interest: We declare no conflict of interest.

\section{References}

1. Cosgrove, W.J.; Loucks, D. Water management: Current and future challenges and research directions. Water Resour. Res. 2015, 51, 4823-4839. [CrossRef]

2. Onyango, A.E.; Okoth, M.W.; Kunyanga, C.N.; Aliwa, B.O. Microbiological quality and contamination level of water sources in Isiolo County in Kenya. J. Environ. Public Health 2018, 2018. [CrossRef]

3. Boretti, A.; Rosa, L. Reassessing the Projections of the World Water Development Report. NPJ Clean Water 2019, 2, 1-6. [CrossRef]

4. Mishra, B.P. Water pollution and food contamination in relation to health hazards: Food safety as a global challenge. Pollutry 2008, 27, 395-400.

5. Dubois, O. The State of the World's Land and Water Resources for Food and Agriculture: Managing Systems at Risk; Dubois, O., Ed.; Earthscan: London, UK, 2011; p. xxii+285.

6. Decol, L.T.; Casarin, L.S.; Hessel, C.T.; Batista, A.C.F.; Allende, A.; Tondo, E.C. Microbial quality of irrigation water used in leafy green production in Southern Brazil and its relationship with produce safety. J. Food Microbiol. 2017, 65, 105-113. [CrossRef] [PubMed]

7. Uyttendaele, M.; Jaykus, L.A.; Amoah, P.; Chiodini, A.; Cunliffe, D.; Jacxsens, L.; Holvoet, K.; Korsten, L.; Lau, M.; McClure, P. Microbial hazards in irrigation water: Standards, norms, and testing to manage use of water in fresh produce primary production. Compr. Rev. Food Sci. Food Saf. 2015, 14, 336-356. [CrossRef]

8. Marino, D.D. Water and food safety in the developing world: Global implications for health and nutrition of infants and young children. J. Acad. Nutr. Diet. 2007, 107, 1930-1934. [CrossRef]

9. Hlavsa, M.C.; Aluko, S.K.; Miller, A.D.; Person, J.; Gerdes, M.E.; Lee, S.; Laco, J.P.; Hannapel, E.J.; Hill, V.R. Outbreaks Associated with Treated Recreational Water-United States, 2015-2019. MMWR 2021, 70, 733. [CrossRef]

10. Esschert, K.L.V.; Mattioli, M.C.; Hilborn, E.D.; Roberts, V.A.; Yu, A.T.; Lamba, K.; Arzaga, G.; Zahn, M.; Marsh, Z.; Combes, S. Outbreaks Associated with Untreated Recreational Water-California, Maine, and Minnesota, 2018-2019. MMWR 2020, 69, 781. [CrossRef]

11. Gelting, R.; Baloch, M. A systems analysis of irrigation water quality in environmental assessments related to foodborne outbreaks. Aquat. Procedia 2013, 1, 130-137. [CrossRef] [PubMed]

12. Kraemer, S.A.; Ramachandran, A.; Perron, G. Antibiotic pollution in the environment: From microbial ecology to public policy. Microorganisms 2019, 7, 180. [CrossRef] [PubMed]

13. Sanderson, C.E.; Fox, J.T.; Dougherty, E.R.; Cameron, A.D.; Alexander, K.A. The changing face of water: A dynamic reflection of antibiotic resistance across landscapes. Front. Microbiol. 2018, 9, 1894. [CrossRef] [PubMed]

14. Tiedje, J.M.; Fang, W.; Manaia, C.M.; Virta, M.; Sheng, H.; Liping, M.; Zhang, T.; Edward, T. Antibiotic resistance genes in the human-impacted environment: A One Health perspective. Pedosphere 2019, 29, 273-282. [CrossRef]

15. Danner, M.C.; Robertson, A.; Behrends, V.; Reiss, J. Antibiotic pollution in surface fresh waters: Occurrence and effects. Sci. Total Environ. 2019, 664, 793-804. [CrossRef]

16. Nappier, S.P.; Liguori, K.; Ichida, A.M.; Stewart, J.R.; Jones, K.R. Antibiotic resistance in recreational waters: State of the science. Int. J. Environ. Res. Public Health 2020, 17, 8034. [CrossRef]

17. Mateo-Sagasta, J.; Zadeh, S.M.; Turral, H.; Burke, J. Water Pollution from Agriculture: A Global Review. Executive Summary. 2017. Available online: http:/ /www.fao.org/3/i7754e/i7754e.pdf (accessed on 10 June 2021).

18. Manyi-Loh, C.; Mamphweli, S.; Meyer, E.; Okoh, A. Antibiotic use in agriculture and its consequential resistance in environmental sources: Potential public health implications. Molecules 2018, 23, 795. [CrossRef]

19. Daou, C.; Salloum, M.; Legube, B.; Kassouf, A.; Ouaini, N. Characterization of spatial and temporal patterns in surface water quality: A case study of four major Lebanese rivers. Environ. Monit. Assess. 2018, 190, 1-16. [CrossRef] 
20. Fouz, N.; Pangesti, K.N.; Yasir, M.; Al-Malki, A.L.; Azhar, E.I.; Hill-Cawthorne, G.A.; Ghany, M.A.E. The contribution of wastewater to the transmission of antimicrobial resistance in the environment: Implications of mass gathering settings. Infect. Dis. Trop. Med. 2020, 5, 33. [CrossRef]

21. Yu, Y.; Zhu, X.; Wu, G.; Wang, C.; Yuan, X. Analysis of antibiotic resistance of Escherichia coli isolated from the Yitong River in North-east China. Front. Environ. Sci. Eng. 2019, 13, 1-9. [CrossRef]

22. Kumar, K.; Gupta, S.C.; Chander, Y.; Singh, A.K. Antibiotic use in agriculture and its impact on the terrestrial environment. Adv. Agron. 2005, 87, 1-54. [CrossRef]

23. Baquero, F.; Martínez, J.-L.; Cantón, R. Antibiotics and antibiotic resistance in water environments. Curr. Opin. Biotechnol. 2008, 19, 260-265. [CrossRef]

24. Batterman, S.; Eisenberg, J.; Hardin, R.; Kruk, M.E.; Lemos, M.C.; Michalak, A.M.; Mukherjee, B.; Renne, E.; Stein, H.; Watkins, C.; et al. Sustainable control of water-related infectious diseases: A review and proposal for interdisciplinary health-based systems research. Environ. Health Perspect. 2009, 117, 1023-1032. [CrossRef] [PubMed]

25. Pruss-Ustun, A.; Bos, R.; Gore, F.; Bartram, J. Safer Water, Better Health: Costs, Benefits and Sustainability of Interventions to Protect and Promote Health. World Health Organization (WHO). Available online: http://apps.who.int/iris/bitstream/handle/ 10665/43840/9789241596435_eng.pdf?sequence=1 (accessed on 10 June 2021).

26. Damania, R.; Desbureaux, S.; Rodella, A.-S.; Russ, J. Quality Unknown: The Invisible Water Crisis; World Bank Publications: Washington, DC, USA, 2019.

27. Mcheik, A.; Awad, A.; Fadel, A.; Mounzer, C.; Nasreddine, S. Effect of irrigation water quality on the microbial contamination of fresh vegetables in the bekaa valley, Lebanon. AJAF 2018, 6, 191-197.

28. Lebanon Crisis 2017-2020 Response Plan. Available online: https:/ /www.ilo.org/wcmsp5/groups/public/---arabstates/---robeirut/documents/publication/wcms_542062.pdf (accessed on 10 June 2021).

29. Kassem, I.I.; Jaafar, H.J. The potential impact of water quality on the spread and control of COVID-19 in Syrian refugee camps in Lebanon. Water Int. 2020, 45, 423-429. [CrossRef]

30. Sulaiman, A.A.A.; Kassem, I.I. First report on the detection of the plasmid-borne colistin resistance gene $m c r-1$ in multi-drug resistant E. coli isolated from domestic and sewer waters in Syrian refugee camps in Lebanon. Travel Med. Infect. Dis. 2019, 30, 117-120. [CrossRef] [PubMed]

31. Jaafar, H.; King-Okumu, C.; Haj-Hassan, M.; Abdallah, C.; El-Korek, N.; Ahmad, F. Water Resources within the Upper Orontes and Litani Basins: A Balance, Demand and Supply Analysis amid the Syrian Refugees Crisis; International Institute for Environment and Development: London, UK, 2016.

32. Jaafar, H.; Ahmad, F.; Holtmeier, L.; King-Okumu, C. Refugees, water balance, and water stress: Lessons learned from Lebanon. Ambio 2020, 49, 1179-1193. [CrossRef] [PubMed]

33. Karnib, A. Assessing population coverage of safely managed wastewater systems: A case study of Lebanon. J. Water Sanit. Hyg. Dev. 2016, 6, 313-319. [CrossRef]

34. Karam, F.; Mouneimne, A.H.; El-Ali, F.; Mordovanaki, G.; Rouphael, Y. Wastewater Management and Reuse in Lebanon. Res. J. Appl. Sci. 2013, 9, 2868-2879.

35. Geara-Matta, D.; Moilleron, R.; El Samarani, A.; Lorgeoux, C.; Chebbo, G. State of Art about water uses and wastewater management in Lebanon. In Proceedings of the World Wide Workshop for Young Environmental Scientists, Arcueil, France, 31 May-4 June 2010.

36. Hmede, Z.; Kassem, I.I. The colistin resistance gene $m c r-1$ is prevalent in commensal Escherichia coli isolated from preharvest poultry in Lebanon. Antimicrob. Agents Chemother. 2018, 62, e01304-e01318. [CrossRef]

37. Hmede, Z.; Jaafar, H.; Kassem, I.I. Emergence of plasmid-borne colistin resistance gene mcr-1 in multidrug-resistant Escherichia coli isolated from irrigation water in Lebanon. Int. J. Antimicrob. Agents 2019, 54, 102-104. [CrossRef]

38. Hassan, J.; Eddine, R.Z.; Mann, D.; Li, S.; Deng, X.; Saoud, I.P.; Kassem, I.I. The mobile colistin resistance gene, mcr-1.1, is carried on IncX4 plasmids in multidrug resistant E. coli isolated from Rainbow Trout aquaculture. Microorganisms 2020, 8, 1636. [CrossRef]

39. Sulaiman, A.A.A.; Kassem, I.I. First report of the plasmid-borne colistin resistance gene (mcr-1) in Proteus mirabilis isolated from domestic and sewer waters in Syrian refugee camps. Travel Med. Infect. Dis. 2020, 33, 101482. [CrossRef]

40. Sourenian, T.; Mann, D.; Li, S.; Deng, X.; Jaafar, H.; Kassem, I.I. Dissemination of multidrug-resistant Escherichia coli harboring the mobile colistin resistance gene mcr-1.1 on transmissible plasmids in the Mediterranean Sea. J. Glob. Antimicrob. Resist. 2020, 22, 84-86. [CrossRef] [PubMed]

41. Hassan, J.; Mann, D.; Li, S.; Deng, X.; Kassem, I.I. Emergence of the mobile colistin resistance gene mcr-1 in multidrug-resistant Escherichia coli isolated from the fecal matter of toddlers in a community. Antimicrob. Agents Chemother. 2021, 65, e00243-21. [CrossRef]

42. Kassem, I.I.; Hijazi, M.A.; Saab, R. On a collision course: The availability and use of colistin-containing drugs in human therapeutics and food-animal farming in Lebanon. J. Glob. Antimicrob. Resist. 2019, 16, 162-164. [CrossRef] [PubMed]

43. Al-Mir, H.; Osman, M.; Azar, N.; Madec, J.-Y.; Hamze, M.; Haenni, M. Emergence of clinical mcr-1-positive Escherichia coli in Lebanon. J. Glob. Antimicrob. Resist. 2019, 19, 83-84. [CrossRef] [PubMed]

44. Salloum, T.; Panossian, B.; Bitar, I.; Hrabak, J.; Araj, G.F.; Tokajian, S. First report of plasmid-mediated colistin resistance mcr-8.1 gene from a clinical Klebsiella pneumoniae isolate from Lebanon. Antimicrob. Resist. Infect. Control 2020, 9, 1-7. [CrossRef] 
45. Osman, M.; Al Mir, H.; Rafei, R.; Dabboussi, F.; Madec, J.-Y.; Haenni, M.; Hamze, M. Epidemiology of antimicrobial resistance in Lebanese extra-hospital settings: An overview. J. Glob. Antimicrob. Resist. 2019, 17, 123-129. [CrossRef]

46. Dandachi, I.; Sokhn, E.S.; Dahdouh, E.A.; Azar, E.; El-Bazzal, B.; Rolain, J.-M.; Daoud, Z. Prevalence and characterization of multi-drug-resistant gram-negative bacilli isolated from Lebanese poultry: A nationwide study. Front. Microbiol. $2018,9,550$. [CrossRef]

47. Dandachi, I.; Fayad, E.; Sleiman, A.; Daoud, Z.; Rolain, J.-M. Dissemination of multidrug-resistant and $m c r-1$ gram-negative bacilli in broilers, farm workers, and the surrounding environment in Lebanon. Microb. Drug Resist. 2020, 26, 368-377. [CrossRef] [PubMed]

48. Dandachi, I.; Fayad, E.; El-Bazzal, B.; Daoud, Z.; Rolain, J.-M. Prevalence of extended-Spectrum Beta-lactamase-producing gram-negative bacilli and emergence of $m c r-1$ colistin resistance gene in Lebanese swine farms. Microb. Drug Resist. 2018, 25, 233-240. [CrossRef]

49. Haydar, C.; Nehme, N.; Awad, S.; Koubayssi, B.; Fakih, M.; Yaacoub, A.; Toufaily, J.; Villieras, F.; Hamieh, T. Physiochemical and microbial assessment of water quality in the Upper Litani River Basin, Lebanon. Environ. Earth Sci. 2014, 4, 87-97.

50. Food and Agriculture Organization (FAO). AQUASTAT Country Profile-Lebanon. Available online: http://www.fao.org/3/ca0 344en/CA0344EN.pdf (accessed on 10 June 2021).

51. U.S. Environmental Protection Agency (EPA). Water Quality Standards Handbook: Chapter 3: Water Quality Criteria. EPA-823-B17-001. EPA Office of Water, Office of Science and Technology, Washington, DC. 2017. Available online: https:/ /www.epa.gov/ sites/production/ files/2014-10/documents/handbook-chapter3.pdf (accessed on 10 June 2021).

52. Holcomb, D.A.; Stewart, J. Microbial indicators of fecal pollution: Recent progress and challenges in assessing water quality. Curr. Environ. Health Rep. 2020, 7, 1-14. [CrossRef] [PubMed]

53. Cabral, J.P. Water microbiology. Bacterial pathogens and water. Int. J. Environ. Res. Public Health 2010, 7, 3657-3703. [CrossRef] [PubMed]

54. European Food Safety Authority (EFSA). Report from the Task Force on Zoonoses data collection including guidance for harmonized monitoring and reporting of antimicrobial resistance in commensal Escherichia coli and Enterococcus spp. from food animals. EFSA J. 2008, 6, 1831-4732.

55. Colque Navarro, P.; Fernandez, H.; Möllby, R.; Otth, L.; Tiodolf, M.; Wilson, M.; Kühn, I. Antibiotic resistance in environmental Escherichia coli-a simple screening method for simultaneous typing and resistance determination. J. Water Health 2014, 12, 692-701. [CrossRef]

56. Bailey, J.K.; Pinyon, J.L.; Anantham, S.; Hall, R.M. Commensal Escherichia coli of healthy humans: A reservoir for antibioticresistance determinants. J. Med. Microbiol. 2010, 59, 1331-1339. [CrossRef]

57. U.S. Environmental Protection Agency (US-EPA). Sampling and Consideration of Variability (Temporal and Spatial) for Monitoring of Recreational Waters. Available online: https:/ /www.epa.gov/sites/default/files/2015-11/documents/samplingconsideration-recreational-waters.pdf (accessed on 10 June 2021).

58. Kassem, I.I.; Nasser, N.A.; Salibi, J. Prevalence and loads of fecal pollution indicators and the antibiotic resistance phenotypes of Escherichia coli in raw minced beef in Lebanon. Foods 2020, 9, 1543. [CrossRef] [PubMed]

59. Système D'évaluation De La Qualité De L'eau Des Cours D'eau (SEQ-EAU). Version 2. Available online: https://bretagneenvironnement.fr/systeme-evaluation-qualite-eau-cours-eau-seq-eau (accessed on 10 June 2021).

60. Clinical and Laboratory Standards Institute (CLSI). Performance Standards for Antimicrobial Susceptibility Testing; CLSI: Wayne, PA, USA, 2016.

61. Nguyen, M.C.P.; Woerther, P.-L.; Bouvet, M.; Andremont, A.; Leclercq, R.; Canu, A. Escherichia coli as reservoir for macrolide resistance genes. Emerg. Infect. Dis. 2009, 15, 1648. [CrossRef] [PubMed]

62. European Committee on Antimicrobial Susceptibility Testing. Breakpoint Tables for Interpretation of MICs and Zone Diameters. EUCAST, Version 8.1. 2018. Available online: http:/ / www.eucast.org (accessed on 10 June 2021).

63. Berrazeg, M.; Drissi, M.; Medjahed, L.; Rolain, J.M. Hierarchical clustering as a rapid tool for surveillance of emerging antibioticresistance phenotypes in Klebsiella pneumoniae strains. J. Med. Microbiol. 2013, 62, 864-874. [CrossRef] [PubMed]

64. Smith, L.M.; Mahler, S.A. Food and Waterborne Illnesses. In Tintinalli's Emergency Medicine: A Comprehensive Study Guide; McGraw-Hill: New York, NY, USA, 2016.

65. World Health Organization (WHO). WHO: Waterborne Disease Is World's Leading Killer. Available online: https://www. voanews.com/archive/who-waterborne-disease-worlds-leading-killer (accessed on 10 June 2021).

66. Bashir, I.; Lone, F.; Bhat, R.A.; Mir, S.A.; Dar, Z.A.; Dar, S.A. Concerns and threats of contamination on aquatic ecosystems. In Bioremediation and Biotechnology; Springer: Cham, Switzerland, 2020; pp. 1-26.

67. Walker, D.; Baumgartner, D.; Gerba, C.; Fitzsimmons, K. Surface water pollution. In Environmental and Pollution Science, 3rd ed.; Brusseau, M.L., Pepper, I.L., Gerba, C.P., Eds.; Elsevier: London, UK, 2019; pp. 261-292.

68. Houri, A.; El Jeblawi, S.W. Water quality assessment of Lebanese coastal rivers during dry season and pollution load into the Mediterranean Sea. J. Water Health 2007, 5, 615-623. [CrossRef]

69. Dufour, A.P. Ambient Water Quality Criteria for Bacteria-1986; The Standard Division: Washington, DC, USA, 1986 ; Volume 86.

70. European Comission (EC). Commission notice on guidance document on addressing microbiological risks in fresh fruits and vegetables at primary production through good hygiene. Off. J. Eur. Union C 2017, 163, 1-40. 
71. Iglesias, R.; Ortega, E.; Batanero, G.; Quintas, L. Water reuse in Spain: Data overview and costs estimation of suitable treatment trains. Desalination 2010, 263,1-10. [CrossRef]

72. Spanish Regulations for Water Resuse Royal Decree 1620/2007 of 7 December. Available online: https:/ / www.iwa-network.org/ filemanager-uploads/WQ_Compendium/Database/Selected_guidelines/042_2.pdf (accessed on 10 June 2021).

73. The Litani River Authority (LRA). Main Problems and Risks Threatening the Litani River Water. Available online: https: / / www.litani.gov.lb/en/?page_id=71 (accessed on 10 June 2021).

74. Kouzayha, A.; Al Ashi, A.; Al Akoum, R.; Al Iskandarani, M.; Budzinski, H.; Jaber, F. Occurrence of pesticide residues in Lebanon's water resources. Bull. Environ. Contam. Toxicol. 2013, 91, 503-509. [CrossRef]

75. Darwish, T.; Shaban, A.; Masih, I.; Jaafar, H.; Jomaa, I.; Simaika, J. Sustaining the ecological functions of the Litani River Basin, Lebanon. Int. J. River Basin Manag. 2021, 1-15. [CrossRef]

76. Steele, M.; Mahdi, A.; Odumeru, J. Microbial assessment of irrigation water used for production of fruit and vegetables in Ontario, Canada. J. Food Prot. 2005, 68, 1388-1392. [CrossRef] [PubMed]

77. Tongesayi, T.; Tongesayi, S. Contaminated irrigation water and the associated public health risks. In Food, Energy, and Water; Elsevier: Amsterdam, The Netherlands, 2015; pp. 349-381.

78. Castro-Rosas, J.; Cerna-Cortés, J.F.; Méndez-Reyes, E.; Lopez-Hernandez, D.; Gómez-Aldapa, C.A.; Estrada-Garcia, T. Presence of faecal coliforms, Escherichia coli and diarrheagenic E. coli pathotypes in ready-to-eat salads, from an area where crops are irrigated with untreated sewage water. Int. J. Food Microbiol. 2012, 156, 176-180. [CrossRef]

79. Alegbeleye, O.O.; Singleton, I.; Sant'Ana, A.S. Sources and contamination routes of microbial pathogens to fresh produce during field cultivation: A review. Food Microbiol. 2018, 73, 177-208. [CrossRef] [PubMed]

80. Halablab, M.; Sheet, I.; Holail, H. Microbiological quality of raw vegetables grown in Bekaa Valley, Lebanon. Am. J. Food Technol. 2011, 6, 129-139. [CrossRef]

81. Faour-Klingbeil, D.; Kuri, V.; Fadlallah, S.; Matar, G.M. Prevalence of antimicrobial-resistant Escherichia coli from raw vegetables in Lebanon. J. Infect. Dev. Ctries. 2016, 10, 354-362. [CrossRef]

82. Kharroubi, S.; Nasser, N.A.; El-Harakeh, M.D.; Sulaiman, A.A.; Kassem, I.I. First nation-wide analysis of food safety and acceptability data in Lebanon. Foods 2020, 9, 1717. [CrossRef]

83. Staley, Z.R.; Rohr, J.R.; Harwood, V.J. Test of direct and indirect effects of agrochemicals on the survival of fecal indicator bacteria. Appl. Environ. Microbiol. 2011, 77, 8765-8774. [CrossRef] [PubMed]

84. Karkman, A.; Pärnänen, K.; Larsson, D.J. Fecal pollution can explain antibiotic resistance gene abundances in anthropogenically impacted environments. Nat. Commun. 2019, 10, 1-8. [CrossRef] [PubMed]

85. Agramont, J.; Gutiérrez-Cortez, S.; Joffré, E.; Sjöling, Å.; Calderon Toledo, C. Fecal pollution drives antibiotic resistance and class 1 integron abundance in aquatic environments of the Bolivian Andes impacted by mining and wastewater. Microorganisms 2020, 8, 1122. [CrossRef] [PubMed]

86. Van den Bogaard, A.E.; Stobberingh, E.E. Epidemiology of resistance to antibiotics: Links between animals and humans. Int. J. Antimicrob. Agents 2000, 14, 327-335. [CrossRef]

87. World Health Organization (WHO). WHO Global Principles for the Containment of Antimicrobial Resistance in Animals Intended for Food: Report of a WHO Consultation with the Participation of the Food and Agriculture Organization of the United Nations and the Office International des Epizooties, Geneva, Switzerland, 5-9 June 2000; World Health Organization: Geneva, Switzerland, 2000.

88. Marinescu, F.; Marutescu, L.; Savin, I.; Lazar, V. Antibiotic resistance markers among Gram-negative isolates from wastewater and receiving rivers in South Romania. Rom. Biotechnol. Lett. 2015, 20, 10055-10069.

89. Belachew, T.; Mihret, A.; Legesse, T.; Million, Y.; Desta, K. High level of drug resistance by gram-negative bacteria from selected sewage polluted urban rivers in Addis Ababa, Ethiopia. BMC Res. Notes 2018, 11, 1-6. [CrossRef] [PubMed]

90. Blaak, H.; Lynch, G.; Italiaander, R.; Hamidjaja, R.A.; Schets, F.M.; de Roda Husman, A.M. Multidrug-resistant and extended spectrum beta-lactamase-producing Escherichia coli in Dutch surface water and wastewater. PLoS ONE 2015, 10, e0127752. [CrossRef] [PubMed]

91. Chmiel, M.; Lenart-Boroń, A. Prevalence of antibiotic-resistant Escherichia coli strains in selected rivers of Lesser Poland. Int. J. Environ. Sci. Technol. 2019, 16, 391-400. [CrossRef]

92. Landers, T.F.; Cohen, B.; Wittum, T.E.; Larson, E.L. A review of antibiotic use in food animals: Perspective, policy, and potential. Public Health Rep. 2012, 127, 4-22. [CrossRef]

93. Papp-Wallace, K.M.; Endimiani, A.; Taracila, M.A.; Bonomo, R.A. Carbapenems: Past, present, and future. Antimicrob. Agents Chemother. 2011, 55, 4943-4960. [CrossRef] [PubMed] 